\title{
Hotspot mapping in the Celtic Sea: An interactive tool using multinational data to optimise fishing practices
}

\author{
Calderwood Julia ${ }^{1,{ }^{*}}$, Robert Marianne ${ }^{2}$, Pawlowski Lionel ${ }^{2}$, Vermard Youen ${ }^{3}$, Radford Zachary ${ }^{4}$, \\ Catchpole Thomas L. ${ }^{4}$, Reid David G. ${ }^{1}$
}

${ }^{1}$ Marine Institute, Rinville, County Galway, H91 R673, Ireland

2 IFREMER, Unité de Sciences et Technologies Halieutiques, Laboratoire de Technologie et Biologie Halieutique, 8 rue François Toullec, F-56100, Lorient, France

3 IFREMER, Fisheries Ecology and Modeling Research Unit, Rue de l'lle d'Yeu, 44311, Nantes, France

${ }^{4}$ CEFAS, Lowestoft, NR33 OHT, England, UK

* Corresponding author : Julia Calderwood, email address : Julia.calderwood@marine.ie

\begin{abstract}
:
As a result of the introduction of the Landing Obligation in European fisheries there is a need to equip industry with the tools and knowledge to avoid unwanted catches. Optimising fishing practices in terms of time and location fished have been acknowledged as being important in modulating catch composition. Mapping techniques used to identify and manage the spatio-temporal nature of bycatch, however, remain underutilized. Data collected on board commercial fishing vessels by observers provides an important source of information on the component of catches discarded. Using a unique dataset, combining observer data for Irish, French and British vessels operating in the Celtic Sea between 2010 and 2015, maps were developed to identify where catches of quota restricted species or under minimum conservation reference size (MCRS) fish were consistent through time. Different catch metrics, based on CPUE and proportion of species in the catch, were compared as a basis for the maps. Our results indicate that it is possible to target above MCRS catches whilst avoiding below MCRS catches of the same species. Quota restricted species such as haddock can also be avoided whilst targeting other commercially exploited species including whiting. To allow all the information produced to be easily interpreted, the maps have been incorporated into a user-friendly app, to better inform decision making and potentially increase fishing opportunities under the Landing Obligation.
\end{abstract}

Keywords : Landing obligation, Discards, Consistent maps, Fishing tactics, Shiny app, Celtic sea 


\section{1. Introduction}

25 The reduction of discards and unwanted catch in European fisheries was identified as one of the 26 main objectives of the EU Common Fisheries Policy reforms in 2013, resulting in the introduction of 27 the Landing Obligation (LO), whereby discarding of quota species in European fisheries will be 28 prohibited by 2019 [1,2]. Implementation of the LO presents major challenges especially for mixed 29 fisheries [3]. Whilst improvements in gear selectivity can help in reducing unwanted catches there 30 remains a need to avoid areas with an abundance of unwanted catch if this legislation is to be 31 adhered to [4-7]. Altering fishing practices in terms of time and location of fishing has, therefore, 32 been acknowledged as being important in optimising catch composition and extending fishing 33 opportunities [4,8-10]. 
For fishermen to effectively target their fishing practices it is vital that industry stakeholders are provided with as much information about the distribution of fish as possible. Survey data collected from research vessels, observer data collected from commercial fishing vessels and catch information from logbooks or electronic monitoring technology coupled with VMS (vessel monitoring systems) data can be used to produce maps that identify species hotspots [11-14]. The inclusion of discards in such data sources provides more precise estimates of catch than just using landings data alone [15]. Maps produced from observer data could, therefore, provide a real insight into the spatial distribution of all species caught by commercial vessels. Fishing suitability and bycatch hotspot maps have indeed been developed using fisheries data and statistical modelling techniques to assist in forecasting fish distributions and to provide insight into regional discarding issues in locations including; the Canadian Arctic, Danish waters, the Spanish Mediterranean and the northwest Atlantic [4,16-18]. Whilst such advanced spatial analysis techniques and methods used to identify and manage the spatio-temporal nature of bycatch have been developed in a number of global fisheries they generally remain underutilized by industry $[16,19]$. In addition to developing such maps there is a need to ensure the resultant outputs are presented in an easily digestible and accessible format. Further, it is essential that spatial analysis and mapping are based on as much suitable data as possible. Whilst observer data does provide information on the whole catch and not just the component later landed there are problems associated with discard sampling from observers, including low sampling frequency and irregular sampling design [20].

The Celtic Sea is an area on the western edge of Europe extending from the western Channel, south of England up around the west coast of Ireland, across the continental shelf to the west of Scotland. The Celtic Sea is an extensively fished ecosystem, providing valuable fisheries for several species, which often co-occur within a mixed species assemblage [21]. Due to its geographical location this area supports a number of international fleets including those from Ireland, France, and the UK. Whilst individual EU member states are required to collect fisheries data as part of the EU data collection framework (Council regulation (EC) No 199/2008) there is no obligation to share this data directly with other EU member states. Sharing and compiling data, especially that collected by observers, can increase sampling frequency and coverage and assist in overcoming some of the issues associated with the sparse nature of observer data. Further, the mixed nature of demersal fisheries in this area and their complex spatial structure [12] make the Celtic Sea an ideal area to make use of such a data sharing exercise to help better identify spatial patterns in fish distributions. 
A unique tri-national dataset was created by combining observer data from Irish, French and British vessels operating in the Celtic Sea for the first time. This dataset was then used to identify areas where catches of species subject to TAC (total allowable catch), for both the above and below minimum conservation reference size (MCRS) components of the catch, were consistent over time. This use of consistent patterns in the catch, rather than simply calculating mean values from observer data over multiple years, is a novel way of approaching hotspot mapping. The resultant maps can be used to identify hotspots of catches that fishermen may want to better target or avoid to optimise catches under the landing obligation. Further to the development of this methodology an interactive app was developed so that fishermen can extract tailored information, ultimately helping to inform where to fish to reduce bycatch and reduce the risk of choke events [22]. If this approach does prove useful to them, it may also increase their motivation to share their own data and potentially increase the accuracy and/or increase the temporal resolution of the results.

\section{Methods}

\subsection{Data}

Data collected by onboard observers working on Irish, British and French demersal vessels operating in the Celtic Sea between 2010 and 2015 were used in the analyses. Data were collected by each member state as part of the EU data collection framework (Council regulation (EC) No 199/2008). The exact structure of each nation's observer programme does vary with the selection of vessels being stratified by gear type for the British fleet, by metier in France and stratified by area of operation (ICES Vlab, VIla or VIIb-k) in Ireland with the selection probability of Irish vessels being proportional to their landings in the same quarter of the previous year [23-26]. Onboard sampling protocols also vary between each national observer programme although in each case components of both the discarded and retained catches are sampled, weighed and measured to allow estimates of total catches and discards to be made at fleet level [23-25,27]. In most instances every individual within a sub sample, of known weight, from each haul is identified and measured, with records of the total catch weight of the associated haul also being taken. For our analysis, this sub-sample data collected as part of each observer programme were raised to haul level, based on the total catch weight, using length-weight keys for each species sampled. This procedure was done at a national level, according to each research centres protocols, prior to the data being amalgamated into one dataset. Despite some differences in these raising procedures, each nation produced a dataset with catch weights being assigned to individual hauls, for which there was information on the start and 
end positions, in addition to tow duration, thus allowing all three datasets to be merged and analysed together as described in section 2.2

102

103

Observer data were specifically used as it is the only reliable source of information on the component of catches that are discarded at sea, providing biological data on the whole catch and not just fish and shellfish later landed. In addition meta-data such as the position and duration of hauls, gear and mesh size used, vessel type and vessel size are all collected by observers. It is acknowledged that within mixed fisheries in particular the interactions that exist between fishing units and across species should not be ignored when utilising and interpreting fisheries data [28]. As such we consider it important to consider fleet segments separately with regard to spatial catch patterns. Due to the resolution of observer data, data from individual metiers were too sparse for our analyses so in the first instance we concentrated on data collected on-board TR1 (mixed whitefish) vessels and TR2 (Nephrops) vessels as defined by EU regulation, to test our hotspot mapping methodology. These gear types can be defined as those operating bottom trawls, Danish seine nets and similar towed gear with cod end mesh sizes between $70 \mathrm{~mm}$ and $100 \mathrm{~mm}$ for TR2 vessels and above 100mm for TR1 vessels, but excluding beam trawls in both cases [29]. Details of the sampling structure within these two categories and how different gear types are represented within them are further detailed in Table 1 and Table 2. Preliminary analysis indicated that for both vessel categories the area fished by sampled vessels was representative of the fishing effort of the fleet, as shown by examining VMS data, although the relationship between the spatial sampling effort of observers and fleet wide fishing patterns was closer for TR2 vessels compared to TR1 vessels (supplementary material; S1). Table 1 here.

Table 2 here.

\subsection{Mapping Methodology}

The geographical midpoint of all hauls were calculated as the mean of the Euclidean distance between the start and end point of each fishery operation and catch data assigned to this point. Catch data were then assigned to 0.2 by 0.2 degree grid cells to ensure individual vessel and national data could not be identified. The proportion of the haul by weight $(\mathrm{kg})$ for both the below and above MCRS component of the catch for key demersal species subject to a TAC (cod, haddock, whiting, hake, megrim, monkfish, saithe, pollack, plaice, ling and sole) was calculated. Mean annual 
proportion values, based on total catches, were calculated for each grid cell and grid cells were subsequently binned into five categories based on $20 \%$ intervals

In addition to calculating the proportion of each species in the catch by weight and producing maps based on these data the above mapping procedure was repeated using a second metric of catch per unit effort (CPUE). CPUE ( $\mathrm{kg} \mathrm{hr}^{-1}$ ) was calculated from the original datasets by dividing the total weight of both below and above MCRS TAC species caught in each haul by the total haul duration. Again, mean annual values were calculated for each grid cell and subsequent values were divided into five equal quantiles, following the removal of zero catches. An additional amalgamated map was created for the whole time period studied by identifying grid cells that were consistently within the same quantile over multiple years.

In addition to determining annual catch patterns, seasonal patterns were investigated by sub setting the observer data into four datasets based on the quarter of the year in which fishing operations took place. Mean quarterly values per grid cell for each individual year were calculated as before again being binned or assigned to quantiles with amalgamated quarterly maps being produced for both proportion and CPUE data. All analyses were undertaken in R 3.4.3 [30].

Fig 1 here.

\subsection{Comparison with mean data}

The gridded hotspot maps produced, identifying where catch composition remained consistent over time, were compared with a map based solely on mean catch values to determine the effectiveness of this new methodology. The original dataset was stratified by year and then randomly split into two main subsets, a training dataset including $90 \%$ of the total observations and a test dataset containing the remaining $10 \%$ of the data.. The gridded mapping procedure, as described in section 2.2, was performed using the training data. Individual data points in the test dataset were also 
165 categorised based on the quantile they fell into. Additional maps for the $<$ and $>$ MCRS components of each TAC species were produced by calculating the overall mean proportion by weight and mean CPUE for all hauls in each grid cells using the training data. The quality of all of these mapping procedures was then assessed using the test data. Nearest neighbour analysis was run to identify the closest grid cells in each map to individual data points in the corresponding testing dataset. Test dataset points closer to the edge of the mapped area than to populated grid cells were removed from the analysis. For each map agreement between the categories of the catch in the testing dataset and that of the closest grid cell were calculated. Cohen's Kappa was calculated using the psych package in $R$ [31] for each map in comparison with the testing dataset, as this statistic calculates the proportion of agreement after chance agreement has been removed $[32,33]$. The above methodology was repeated 1000 times for each map comparison and respective mean Cohen's Kappa values and associated standard deviations were calculated.

\subsection{Interpolation}

The resultant gridded hotspot maps show where consistent proportions or volumes of certain species within the catch are likely to be found over multiple years. This provides valuable information to inform where to target fishing activities and optimise catches in relation to available quotas. To provide a more user friendly end product the gridded maps were interpolated using inverse distance weighting using gstat in $\mathrm{R}[30,34]$. Due to the grid structure of the data a number of suitable interpolation techniques were compared prior to the final interpolation technique being applied. Proximity polygons, nearest neighbour analysis and inverse distance weighting techniques were validated against a test dataset and the root mean square error (RMSE) was calculated for each method [35]. The inverse distance weighting interpolation consistently produced the lowest RMSE values for each interpolated map and thus this method was used throughout our analyses. Interpolation was also applied to the grids at this stage, rather than on the raw data prior to gridding, to ensure data from annual maps could be overlapped on the same scale, allowing for the retention of consistent data as previously described.

\subsection{App Development}

To produce a user friendly and interactive tool for use by stakeholders an app, which is available at https://shiny.marine.ie/discardless/, was developed using Shiny and Leaflet in R [36,37]. Layers were extracted from the interpolated maps based on the original bin and quantile categories. These were converted to spatially referenced shape files and saved separately. The use of interactive maps 
1, Quarter 2, Quarter 3 or Quarter 4) as well as the species they wish to target or avoid. For each species selected, the user can specify whether they are interested in avoiding the below or above MCRS component of the catch, or both of these. The user is then able to toggle the levels of catch they either wish to target or avoid, selecting either the minimum proportion of the selected species or minimum level of CPUE of interest (Fig. 2). Multiple target and non-target species can be selected at once and semi-transparent map layers are displayed on an interactive map, identifying where selected levels of catch are likely to occur.

Fig 2 here.

\subsection{Simulation Study}

209 A modelling approach was adopted to assess how successful the mapping app could be at assisting 210 an Irish demersal trawler to avoid choke species if it had been used in the Celtic Sea in 2015. 211 Haddock has been identified as a key choke species for Irish TR1 vessels due to the restrictive quotas available for this species [38], with the early fulfilment of haddock quotas preventing further fishing for less quota restricted species [22]. Haddock and whiting are two species that are frequently found to co-occur within the demersal fishery but haddock quotas are often substantially lower than those available for whiting in Ireland. During January 2014 for example, 2 tonnes of haddock were available per Irish vessel operating in ICES areas VIIb-k, VII, IX and X compared with 25 tonnes of whiting in Vllb-k [39]. Thus we used the app to highlight areas where haddock catches were likely to be low and >MCRS whiting catches were likely to be high to identify where best to fish to avoid choking on haddock and extend fishing opportunities for whiting under the LO. From this map six scenarios were examined; 1 . Unrestricted Fishing (fishing could take place anywhere in the area bound by $14^{\circ} \mathrm{W}, 3^{\circ} \mathrm{W}, 50^{\circ} \mathrm{N}$ and $\left.53^{\circ} \mathrm{N}\right)$, 2. Fishing in areas with low CPUE of < MCRS haddock (avoiding juvenile haddock), 3. Fishing in areas with low CPUE of > MCRS haddock (avoiding marketable haddock), 4. Fishing in areas with low CPUE of haddock (outside of scenarios 2 and 3 combined, so avoiding both sizes of haddock), 5. Fishing in areas with high CPUE of > MCRS whiting, 6. Fishing in areas with high whiting and low haddock CPUE (where 5 does not overlap 4).

The tri-national observer dataset for TR1 vessels operating in 2015 was used to create interpolated base maps of CPUE $\left(\mathrm{kg} \mathrm{h}^{-1}\right)$ for both below and above MCRS haddock and whiting catches. For each of the scenarios, points were randomly sampled (with replacement) from the appropriate area, as 
detailed above. Sampling of points within each area was stopped once a haddock quota of two tonnes had been reached and the whiting caught at this time was recorded. The mean number of hours fished prior to the haddock quota being reached was also inferred. This modelling exercise was repeated 1000 times for each scenario and resultant mean simulated catch values and fishing times were calculated.

235

236

\section{Results}

237 The hotspot maps, an example of which can be seen in Figure 2, have been created for the above 238 and below MCRS component of the catch for all demersal species subject to a TAC. To better focus 239 comparison and analysis of the results this paper will focus on three key species; haddock, whiting 240 and cod. Both haddock and whiting have been recognised as "choke" species [40] in the Celtic Sea 241 with the perception from multiple member states that catches for these species exceed TAC [41]. 242 Further current ICES advice states that when the MSY approach is applied there should be zero catch 243 or TAC zero in the Celtic Sea and western English channel for cod in 2019 [42]. With particularly low 244 cod quota share available for the UK as well as Ireland in this region in addition to the latest TAC zero 245 advice cod also poses a significant choke risk for all vessels operating in the Celtic Sea $[42,43]$. 246 Examples of how the information in these maps compares and contrasts for these species are 247 described below.

\subsection{Comparison with mean data}

251 The results in Table 3 show that there was generally greater agreement between the hotspot maps 252 we developed for both TR1 and TR2 vessels and a subset of original data points than compared with maps based on mean values from 2010 to 2015 for all maps tested. For TR1 vessels the greatest agreement between the test dataset and our maps was for above MCRS whiting for proportion data $(0.43 \pm 0.06)$ and below MCRS whiting for CPUE data $(0.41 \pm 0.06)$. Thus for these size classes of whiting the consistencies in catch patterns are most reflected in real-catch data. For TR2 vessels there was greater agreement between the mean proportion data and test data than the hotspot maps for > MCRS whiting, but in all other instances there is greater agreement with the hotspot maps. The below MCRS haddock hotspot map showed the greatest agreement with test data for all proportion maps for the TR2 vessels $(0.51 \pm 0.06)$. The greatest agreement between all maps was 
catch metrics there is a $50 \%$ split between the proportion and CPUE hotspot maps having greatest agreement with the raw data.

Table 3 here.

266

267

\subsection{TR1 vs TR2 vessels}

Hotspot maps for TR1 and TR2 vessels were constructed separately and Figure 3 shows how the 269 maps identifying areas with consistent levels of above MCRS haddock CPUE compare for these vessel types. There are similarities between these two maps with both having a large area of the median category of CPUE in the Irish Sea above $52^{\circ} \mathrm{N}$. Similarly to the west of Ireland TR1 vessels consistently catch the largest amounts of haddock centred along $52.5^{\circ} \mathrm{N}$, with TR2 vessels having an area with high haddock catches at $52.7^{\circ} \mathrm{N}$. Unlike TR1 vessels there is a large area where TR2 vessels are likely to have catches with the highest haddock CPUE centred around $51.5^{\circ} \mathrm{N}$ and $7.5^{\circ} \mathrm{W}$. The hotspot map for TR2 vessels also shows an area with very low catches between $50-50.5^{\circ} \mathrm{N}$ and $8-8.5^{\circ} \mathrm{W}$ that is not evident for TR1 vessels.

Fig 3 here.

\subsection{CPUE vs Proportion}

281

282

Fig 4 here.

Both CPUE $\left(\mathrm{kg} \mathrm{hr}^{-1}\right)$ and proportion by weight in the catch were used as metrics to identify hotspots 285 of key TAC species. Figure 4 shows an example of how these two metrics compare for above MCRS haddock in the Celtic Sea. There are areas with consistently high levels of haddock CPUE within the catch throughout the region with substantial hotspots to the west of Ireland centred around the coordinates $52.5^{\circ} \mathrm{N} 11.0^{\circ} \mathrm{W}$ (Fig 4.A). There are very few areas where catches of above MCRS 289 haddock consistently constitute at least $20 \%$ of the catch (Fig4.B). High proportions of haddock are 290 identified closer in towards the coast than with the CPUE data although some patterns are similar between the two maps along the west coast of Ireland at around $52.8^{\circ} \mathrm{N} 9.6^{\circ} \mathrm{W}$ and along the south 
west coast at $52.1^{\circ} \mathrm{N} 7.2^{\circ} \mathrm{W}$. Less relief is evident on the map representing the proportion of haddock 293 (Fig4.B) as few catches were identified with greater than $60 \%$ of haddock in the catch.

\subsection{Below MCRS vs Above MCRS catches}

295

296

Fig 5 here.

297

All species maps were created for two size categories based on fish either below or above MCRS, allowing for a comparison of the distribution of these two size categories amongst and between species. When comparing whiting catches the largest volumes of above MCRS fish are caught in an area centred around the coordinates $51.1^{\circ} \mathrm{N} 6.85^{\circ} \mathrm{W}$ (Fig. 5B). The majority of points with the greatest CPUE of below MCRS whiting are also encompassed within this area. Areas with high CPUE of below MCRS whiting do, however, cover a much smaller area compared to the above MCRS component of the catch. There is an additional area centred at $53.0^{\circ} \mathrm{N} 10.0^{\circ} \mathrm{W}$ where high levels of both below and above MCRS whiting catches are recorded. Small distinct hotspots, representing the highest CPUE category, cover a total area of less than $651 \mathrm{~km}^{2}$ for below MCRS catches compared to $4204 \mathrm{~km}^{2}$ for the above MCRS catches in the same CPUE category. There are also a few distinct patches identified as having a high likelihood of high above MCRS catches where there are no below MCRS catches identified, namely along the $52.5^{\circ} \mathrm{N}$ latitude line and just off of the south west coast of Ireland.

\subsection{Seasonal variation}

313 Seasonal variation in catches can be identified by examining amalgamated quarterly rather than annual data. When comparing areas where there are likely to be consistent levels of CPUE of above MCRS cod, over each quarter, seasonal patterns can be seen (Fig.6). Throughout the year the higher cod catches are mainly concentrated within area VIIg. Moving from quarter one to quarter two, there is a southward expansion in the areas within the two highest CPUE categories whilst the extent of the medium catch categories retracts in from the west. During the third quarter of the year the extent of all but the lowest CPUE layer of the map expand to cover larger areas, extending up the west coast of Ireland. In the final quarter of the year these layers retract again with the areas with the highest cod CPUE moving towards the south west of ICES area VIIg and north of VIIf. 
Fig 6 here.

\subsection{Species Comparison}

The same metrics (CPUE or proportion) can be used to compare the likelihood of different species co-occurring. The area with consistent proportions of haddock in the catch over multiple years in the Celtic Sea for example is much greater than that of whiting (Fig.7). No areas are identified as having consistent proportions of whiting in the catch south of the $52.5^{\circ} \mathrm{N}$ latitude line and west of the $9^{\circ} \mathrm{W}$ longitude line (Fig.7B). There is a distinct chance of catching haddock in this area, with some hotspots of up to $60 \%$ of haddock being identified here (Fig.7A). There is, however, overlap of the haddock and whiting map extents, especially within ICES area VIIg. Overall there are relatively small areas being noted as consistently having at least $20 \%$ of haddock and whiting in the catch (approximately $5280 \mathrm{~km}^{2}$ compared to $3215 \mathrm{~km}^{2}$ respectively).

Fig 7 here.

\subsection{Shiny App}

All of the maps produced provide useful information that can be compared in numerous ways depending on the user's interests and objectives. Providing the maps in an interactive app thus provides the opportunity to pick those layers of interest to easily compare and contrast. Figure 2, for example, shows the overlap of four different layers. The first two are species that fishers might wish to target. Both above MCRS cod and whiting have been selected as the target species, with the level of CPUE being set to include the top $40 \%$ of catches identified during the mapping analysis. Below MCRS haddock and whiting are selected as the non-target species, with the layers highlighting the three highest levels of CPUE identified. The resultant overlap of all of these layers is displayed within an interactive map layer. Although there are overlaps between all four of the layers there are distinct areas that highlight where just the target species are likely to be found (in light and dark green in Fig.2). For example there is an extensive area in the north east of the Celtic sea between the coasts of Ireland and Wales where high levels of both above MCRS cod and whiting were found with no below MCRS catches of these two species. 


\subsection{Simulation Study}

354

355

356

357

In our modelling exercise, when examining the mean whiting catch at the point the monthly haddock quota is reached for an Irish vessel operating in the Celtic Sea region, the lowest amount of whiting was caught in Scenario 1 when fishing was unrestricted (Fig. 8B, mean=1710kg). As a consequence of a very restrictive quota, the whiting catch at the point of the haddock choke was also restricted for scenario 2 before slightly increasing for scenarios 3 and 4 successively. Interestingly the whiting catch at the point of the haddock choke peaks at Scenario 5 (mean $=2609 \mathrm{~kg}$ ), when solely high whiting areas are being targeted compared to the slightly lower whiting catches in scenario 6 where fishing was restricted to the areas where high whiting catches are not overlapped with the high haddock catches (mean=2441kg). When examining the time fished at the point the haddock choke was reached the whiting catch patterns are reflected for the first 4 scenarios, with the time increasing from 38 hours of fishing within the month at scenario 1 to 59 hours within the month at scenario 4 (Fig.8B). For scenarios 5 (high whiting) and 6 where fishing is targeting the high whiting, low haddock areas the time available for fishing is reduced to just 31 and 30 hours respectively, resulting in much more economical fishing than scenario 1 to 4 .

Fig 8 here.

\section{Discussion}

Hotspot mapping provides useful information to allow the optimisation of fishing activity to better target certain species whilst avoiding unwanted and quota restricted catch. Observer data, collected from commercial fishing vessels, provides an ideal basis for such maps as these data include the discarded component of catches, in addition to landings. The sparse coverage of observer data and limited sampling of commercial vessels can present problems when trying to identify patterns in fish distributions. By combining data, for the first time, from three EU member states for commercial vessels operating within the Celtic Sea, we were able to produce maps highlighting where catches of TAC species show consistent patterns over multiple years. By adopting a new hotspot mapping methodology to utilise this unique dataset we have produced maps that provide more accurate data than just mean catch rates. Further by using the output of these maps in an interactive app we have produced a tool that can easily be used by stakeholders to help inform decisions on where to fish to reduce unwanted catches and potentially extend fishing opportunities under the Landing Obligation. 
The unique hotspot mapping methodology developed in this paper identifies areas with consistent catches over time. There are some important assumptions made when using and analysing observer data. These include assuming observer data is representative of the entire fleet, especially with regard to differences in the observer program design between the UK, Ireland and France. There is the potential for additional variation between individual vessels, and the efficiency with which they may be able to avoid unwanted catches, that should be considered when utilising observer data. Observer data remains an important data source, however, as in instances where fisheries are not fully documented or audited using electronic monitoring systems it provides the only source of information on the component of the catch that is discarded at sea. The use of this data to identify consistent patterns in the catch, rather than mean values of observer data, is not only a novel way of approaching hotspot mapping but our analysis indicates that results from the hotspot maps generally more closely represent fishing data than mean maps. As previously highlighted by Gerritsen et al., (2012) species composition of retained catches from demersal otter trawls in Irish waters show considerable spatial structure. Certainly the ability to highlight this structure and consistency with this hotspot mapping methodology, excluding areas with high variability in catch composition, presents stakeholders with data that better highlights where both those catches they want to target or avoid are likely to occur.

There is some variation between catch metrics, vessel type and species as to how well our hotspot maps represent fishing data collected by observers, in part due to how variable the data is between years for each of these variables. For TR1 vessels for example hotspot maps match observer data less well for the below MCRS components of the catch compared to >MCRS hotspot maps. This in part may be due to vessels successfully avoiding juvenile catches as these fish cannot be legally landed. With distinct nursery grounds for a number of commercially important species having been 409 identified around the coast of the British Isles $[45,46]$ it is possible to avoid large aggregations of small fish. This spatial avoidance coupled with larger mesh sizes in TR1 gears, allowing for the escape of juveniles [47,48], may further reduce the catches of undersize fish. Thus with smaller quantities of below MCRS fish being caught and recorded by observers it could be harder to identify areas with 413 consistent catches. Further there could be greater variability in the data set concerning <MCRS 414 catches over the period of study due to changes in gear selectivity as the mandatory use of a square 415 mesh panel (SMP) for demersal fisheries in the Celtic Sea was introduced in 2012 [49]. The 416 uncertainty associated with these maps should therefore be acknowledged and presented to final users and taken into consideration when informing decision making. Overall, however, this 
methodology remains a strong tool to inform decision making to optimise catches under the restrictions presented by the Landing Obligation.

420

Vessels operating different gears and targeting different fisheries are likely to have different catch profiles $[28,50]$. When comparing separate hotspot maps created from TR1 and TR2 vessels there were apparent differences, although some overall patterns reflecting species distribution were seen in both. TR2 gears, with mesh sizes between 70 and $99 \mathrm{~mm}$, are usually used to target Nephrops norvegicus [29]. Nephrops fishing grounds are restricted spatially to areas with large scale mud patches, which allows for Nephrops to build their burrows, with a distinct seasonality also existing within the fishery [51-53]. This associated concentration of fishing activity in time and space for this gear type, compared with TR1 vessels which target mixed demersal fisheries, will likely contribute towards the main differences seen between these two sets of maps. The differences highlighted between these two maps indicate it is important to consider different fleet segments and ensure stakeholders targeting different fisheries are provided with the information most relevant to them. Further these differences highlight how the adoption of gears with greater selectivity may be more important for certain fisheries that are more spatially restricted, including those targeting Nephrops, as there are fewer options to relocate fishing activity to better optimise catches.

Two catch metrics were used to identify where similar catches are expected to occur over time. CPUE gives an indication of how the volume of a species in a catch varies. When trying to avoid nontarget, quota restricted species it would make sense to avoid areas where there is increased probability of high CPUE catches. When targeting commercially exploited species stakeholders are likely to be drawn to areas with high CPUE due to the associated economic incentives $[8,54,55]$. It is also important to consider the proportion of the target species within the catch and how clean the catch is if bycatch is to be avoided. Thus it may be important to consider the information provided by both of these metrics. Our example comparing CPUE and proportion maps for above MCRS haddock shows how these two metrics compare and contrast. There is some agreement between the two maps as to where hotspots of haddock occur, and identifying these areas would be beneficial to best target fishing. There is certainly less relief in the maps based on proportion by 447 weight and this is especially true of the below MCRS component of the catch where often there is 448 never greater than $20 \%$ of the catch by weight. For these cases the CPUE map provides more 449 detailed information as data categories are based on quantiles rather than pre-defined equal intervals. However, it would also be possible to define different intervals that provide more relief for 
these examples, and this would be the type of information that stakeholders could provide to refine the app to best suit their needs.

453

Under the LO all catches of TAC species, regardless of size, will count against quotas [1]. Thus it will 455 be important for fishers to avoid below MCRS fish as this component of the catch counts against quotas but provides no or limited income if landed. It has certainly been recognised that there is a positive relationship between depth and fish size for a number of demersal species [56-58]. Our examination of hotspot areas for <MCRS whiting catches indeed shows a concentration of catches in the shallower waters along the coast of Ireland. Areas with consistently high catches of >MCRS fish are much more widespread across the Celtic Sea area, and for whiting it is possible to identify areas to target large, marketable fish whilst reducing the chances of catching the smaller fish.

The hotspot mapping method presented identifies areas with consistent proportions or volumes in the catch over time. Obviously fish populations are mobile often displaying seasonal movements and migrations [59-61]. Examining how cod distributions vary with season certainly shows how important it is for stakeholders to consider the data provided in these maps at greater temporal resolution than just annually. Due to the resolution of observer data used in this work, quarterly data is currently the finest temporal resolution that the maps can be divided into. This still provides greater detail than solely presenting annual data and allows fishermen to consider how the dynamics of fish stocks over the course of a year requires seasonal adaptation to fishing practices. If, 471 however, we had access to more reliable and consistent data collected by the fishers themselves, 472 the maps could become more accurate and be presented with finer temporal and spatial resolution. 473 Indeed there are a number of successful examples from fisheries around the world where near real474 time information, provided by commercial vessels, assists industry in avoiding bycatch species. These 475 include real-time closures to avoid cod in Scottish North Sea demersal fisheries, voluntary avoidance 476 of chum salmon in the eastern Bering Sea and real-time closures to reduce juvenile saithe, haddock 477 and cod discards in the Icelandic cod fishery [63-65]. Thus while the methodology we present here 478 uses the best information currently available on discards in the Celtic Sea the resultant tools could 479 be improved with greater provision of industry data. Such data provision could also aid in identifying environmental variability over time, especially under a climate change context, which may modify species distributions and resultant catch hotspots.

In the Celtic Sea, where there is a mixed demersal fishery and numerous species co-occur it is 484 important to be able to highlight those areas where certain species are less likely to occur together 
to allow fishermen to avoid quota restricted species. Haddock and whiting are two species that cooccur but for which there are often uneven quotas available, resulting in haddock being a key choke species, especially in Irish fisheries [38]. This example of a quota mismatch illustrates how the hotspot maps and resultant map app could be used to inform decisions to best target species for which there is quota available. Simulation modelling of fishing activity based on the mapping app indicates that just better concentrating fishing activity in areas with consistently high catches of the target increases whiting catches prior to the haddock quota being reached. The modelling does indicate, however, that the fishery would still become choked in a relatively short amount of time if efforts were made to maximise on whiting catches. Such restrictions on the Irish fishery were similarly observed by commercial vessels attempting to mitigate against the LO during challenge trials assessing the potential impact of this legislation on the Irish fleet [38]. The associated increases in whiting catches, however, means that fishing efforts could be much more economical, with lower fuel and operational costs being associated with bigger catches. This example focused on TR1 vessels which are often larger and more powerful with the ability to travel further to utilise all of the quotas available to them. For smaller vessels operating primarily in inshore areas it may not be possible to operate more economically when there is a need to travel further from a home port to avoid quota restricted species. However, whilst this is a simplified example of how one choke species might interact with one target for an Irish TR1 vessel it does illustrate that there is real potential for the hotspot maps to inform stakeholders on how to best target those species for which there is quota available.

505

506 It is clear that these hotspot maps can provide information that could be very useful if stakeholders 507 are to make the most informed decisions when choosing where to fish whilst operating under the LO 508 [4]. A suite of measures from gear adaptations through to the provision of spatial-temporal 509 information will be required for the fishing industry to successfully reduce unwanted catches and meet the legislative requirements of the LO [66]. Indeed globally a number of initiatives exist where commercial data is used to inform vessel operations $[14,63,64]$. Working in an area without fully documented fisheries or the widespread adoption of electronic monitoring, however, we have utilised the available data to provide a much needed additional element to this suite. But to ensure this data is easily accessible and digestible it needs to be presented to industry in the appropriate format. Thus the interactive app was developed to allow stakeholders to pick and choose the information that is relevant to them at any one point in time. The hotspot maps and resultant modelling of fishing activity using the maps indicates that demersal fisheries are likely to be heavily 
industry with as much knowledge and information as possible, however, it is hoped fishing operations can be optimised with fisheries continuing to be profitable whilst operating under the LO.

521

522

523

524

525

526

527

528

529

530

531

532

533

534

535

536

537

538

539

540

541

542

543

544

545

546

547

548

549

550

551

552

553

554

555

\section{Acknowledgements}

This work has been funded by the European Union's Horizon 2020 research and innovation programme under Grant Agreement DiscardLess No 633680.

\section{References}

[1] European Commission, Proposal for a Regulation of the European Parliament and of the Council amending Council Regulations (EC) No 850/98, (EC) No 2187/2005 (EC) No 1967/2006, (EC) No 1098/2007, No 254/2002, (EC) No 2347/2002 and Landing, (EC) No 1224/2009 and repealing (EC) No 1434/98 as regards the landing obligation, 2013.

[2] T.L. Catchpole, A. Ribeiro-Santos, S.C. Mangi, C. Hedley, T.S. Gray, The challenges of the landing obligation in EU fisheries, Mar. Policy. 82 (2017) 76-86. doi:10.1016/j.marpol.2017.05.001.

[3] J.M. Sobrino, M. Sobrino, The CFP: A difficult compromise between relative stability and the discard ban, in: G. Andreone (Ed.), Futur. Law Sea, Springer, Cham, 2017: pp. 23-43.

[4] R. Vilela, J.M. Bellido, Fishing suitability maps: helping fishermen reduce discards, Can. J. Fish. Aquat. Sci. 72 (2015) 1191-1201. doi:doi.org/10.1139/cjfas-2013-0522.

[5] L.O. Mortensen, C. Ulrich, S. Eliasen, H.J. Olesen, Reducing discards without reducing profit: Free gear choice in a Danish result-based management trial, ICES J. Mar. Sci. 74 (2017) 14691479. doi:10.1093/icesjms/fsw209.

[6] B. Herrmann, H. Wienbeck, J.D. Karlsen, D. Stepputtis, E. Dahm, W. Moderhak, Understanding the release efficiency of Atlantic cod (Gadus morhua) from trawls with a square mesh panel: effects of panel area, panel position, and simulation of escape response, ICES J. Mar. Sci. 72 (2015) 686-696. doi:https://doi.org/10.1093/icesjms/fsu124.

[7] C. Vogel, D. Kopp, F. Morandeau, M. Morfin, S. Méhault, Improving gear selectivity of whiting (Merlangius merlangus) on board French demersal trawlers in the English Channel and North Sea, Fish. Res. 193 (2017) 207-216. doi:10.1016/j.fishres.2017.04.013.

[8] A.N. Tidd, T. Hutton, L.T. Kell, J.L. Blanchard, Dynamic prediction of effort reallocation in mixed fisheries, Fish. Res. 125-126 (2012) 243-253. doi:10.1016/j.fishres.2012.03.004.

[9] I.E. Van Putten, S. Kulmala, O. Thébaud, N. Dowling, K.G. Hamon, T. Hutton, S. Pascoe, Theories and behavioural drivers underlying fleet dynamics models, Fish Fish. 13 (2012) 216235. doi:10.1111/j.1467-2979.2011.00430.x. 
[10] M. Vignaux, Analysis of vessel movements and strategies using commercial catch and effort data from the New Zealand hoki fishery, Can. J. Fish. Aquat. Sci. 53 (1996) 2126-2136. doi:10.1139/cjfas-53-9-2126.

[11] H. Gerritsen, C. Lordan, Integrating vessel monitoring systems (VMS) data with daily catch data from logbooks to explore the spatial distribution of catch and effort at high resolution, ICES J. Mar. Sci. 68 (2011) 245-252. doi:10.1093/icesjms/fsq137.

[12] M. Mateo, L. Pawlowski, M. Robert, Highly mixed fisheries: Fine-scale spatial patterns in retained catches of French fisheries in the Celtic Sea, ICES J. Mar. Sci. 74 (2017) 91-101. doi:10.1093/icesjms/fsw129.

[13] C. Ulrich, H.J. Olesen, H. Bergsson, J. Egekvist, K.B. Hakansson, J. Dalskov, L. Kindt-Larsen, M. Storr-Paulsen, Discarding of cod in the Danish Fully Documented Fisheries trials, ICES J. Mar. Sci. (2015). doi:10.1093/icesjms/fsv028.

[14] L. Kindt-Larsen, E. Kirkegaard, J. Dalskov, Fully documented fishery: A tool to support a catch quota management system, ICES J. Mar. Sci. 68 (2011) 1606-1610. doi:10.1093/icesjms/fsr065.

[15] M. Viana, A.L. Jackson, N. Graham, A.C. Parnell, Disentangling spatio-temporal processes in a hierarchical system: A case study in fisheries discards, Ecography (Cop.). 36 (2013) 569-578. doi:10.1111/j.1600-0587.2012.07853.x.

[16] I. Paradinas, M. Marin, M.G. Pennino, A. López-Quílez, D. Conesa, D. Barreda, M. Gonzalez, J.M. Bellido, Identifying the best fishing-suitable areas under the new European discard ban, ICES J. Mar. Sci. 73 (2016) 2479-2487. doi:10.1093/icesjms/fsw114.

[17] M. Sims, T. Cox, R. Lewison, Modelling spatial patterns in fisheries bycatch: Improving bycatch maps to aid fisheries management, Ecol. Appl. 18 (2008) 649-661. doi:https://doi.org/10.1890/07-0685.1.

[18] A. Cosandey-Godin, E.T. Krainski, B. Worm, J.M. Flemming, Applying Bayesian spatiotemporal models to fisheries bycatch in the Canadian Arctic, Can. J. Fish. Aquat. Sci. 72 (2015) 186-197. doi:10.1139/cjfas-2014-0159.

[19] D.C. Dunn, A.M. Boustany, P.N. Halpin, Spatio-temporal management of fisheries to reduce by-catch and increase fishing selectivity, Fish Fish. 12 (2011) 110-119. doi:10.1111/j.14672979.2010.00388.x.

[20] S. Villasante, C. Pita, G.J. Pierce, C. Pazos, J. Garcia, M. Antelo, J. María, D. Rocha, J. García, L. Hastie, U. Rashid, M. Coll, To land or not to land: How do stakeholders perceive the zero discard policy in European small-scale fisheries?, Mar. Policy. 71 (2016) 166-174. doi:10.1016/j.marpol.2016.05.004.

[21] J.K. Pinnegar, S. Jennings, C.M. O'Brien, N.V.C. Polunin, Long-term changes in the trophic level of the Celtic Sea fish community and fish market price distribution, J. Appl. Ecol. 39 (2002) 377-390. doi:10.1046/j.1365-2664.2002.00723.x.

[22] M. Schrope, Fisheries: What's the catch?, Nature. 465 (2010) 540-542. doi:10.1038/465540a.

[23] L. Borges, E. Rogan, R. Officer, Discarding by the demersal fishery in the waters around Ireland, Fish. Res. 76 (2005) 1-13. doi:10.1016/j.fishres.2005.05.011.

[24] M.J. Rochet, I. Péronnet, V.M. Trenkel, An analysis of discards from the French trawler fleet in 
the Celtic Sea, ICES J. Mar. Sci. 59 (2002) 538-552. doi:10.1006/jmsc.2002.1182.

598

599

600

601

602

603

604

605

606

607

608

609

610

611

612

613

614

615

616

617

618

619

620

621

622

623

624

625

626

627

628

629

630

631

632

633

634

635

[25] R. Enever, A. Revill, A. Grant, Discarding in the English Channel, Western approaches, Celtic and Irish seas (ICES subarea VII), Fish. Res. 86 (2007) 143-152.

doi:10.1016/j.fishres.2007.05.013.

[26] H. Gerritsen, Trip selection for the demersal observer programme, 2017.

[27] L. Borges, A.F. Zuur, E. Rogan, R. Officer, Choosing the best sampling unit and auxiliary variable for discards estimations, Fish. Res. (2005). doi:10.1016/j.fishres.2005.05.002.

[28] P. Marchal, A comparative analysis of métiers and catch profiles for some French demersal and pelagic fleets, ICES J. Mar. Sci. 65 (2008) 674-686. doi:10.1093/icesjms/fsn044.

[29] S. Davie, C. Lordan, Examining changes in Irish fishing practices in response to the cod longterm plan, ICES J. Mar. Sci. 68 (2011) 1638-1646. doi:10.1093/icesjms/fsr052.

[30] R Core Team, R: A language and environment for statistical computing, R Foundation for Statistical Computing, Vienna, Austria, 2017. https://www.r-project.org/.

[31] W. Revelle, psych: Procedures for Psychological, Psychometric, and Personality Research, (2017). https://cran.r_project.org/package=psych.

[32] J. Cohen, A coefficient of agreement for nominal scales, Educ. Psychol. Meas. 20 (1960) 3746. doi:https://doi.org/10.1177/001316446002000104.

[33] H. Gerritsen, D. McGrath, Variability in the assignment of maturity stages of plaice and whiting using macroscopic maturity criteria, Fish. Res. 77 (2006) 72-77. doi:doi.org/10.1016/j.fishres.2005.08.007.

[34] E.J. Pebesma, Multivariable geostatistics in S: the gstat package, Comput. Geosci. 30 (2004) 683-691. doi:https://doi.org/10.1016/j.cageo.2004.03.012.

[35] W. Luo, M.C. Taylor, S.R. Parker, A comparison of spatial interpolation methods to estimate continuous wind speed surfaces using irregularly distributed data from England and Wales, Int. J. Climatol. 28 (2008) 947-959. doi:10.1002/joc.1583.

[36] W. Chang, J. Cheng, J. Allaire, Y. Xie, J. McPherson, shiny: Web Application Framework for R, (2017). https://cran.r-project.org/package=shiny.

[37] J. Cheng, B. Karambelkar, Y. Xie, leaflet: Create Interactive Web Maps with the JavaScript "Leaflet" Library, (2017). https://cran.r-project.org/package=leaflet.

[38] J. Calderwood, R. Cosgrove, S.-J. Moore, I. Hehir, R. Curtin, D. Reid, N. Graham, Assessment of the impacts of the Landing Obligation on Irish Vessels, 2016.

http://www.bim.ie/media/bim/content/publications/Lo,report,2016_final.pdf.

[39] DAFM, Fisheries Management Notice No. 02 of 2014, 2014.

https://www.agriculture.gov.ie/seafood/fisheriesmanagementnotices/fisheriesmanagement notices2014/.

[40] M. Schorpe, Fisheries: What's the catch?, Nature. 465 (2010) 540-542.

[41] D. Rihan, N. Graham, S. Vandamme, North Western Waters Choke Species Analysis, (2017). http://www.nwwac.org/_fileupload/Minutes and Reports/2017/MSG-AC choke analysis/NWW choke analysis_Executive Summary.pdf. 
[42] ICES, ICES Advice on fishing opportunities, catch, and effort; Celtic Seas, Greater North Sea, and Oceanic Northeast Atlantic ecoregions; cod.27.7.e-k, 2018. doi:10.17895/ices.pub.4490.

[43] EU, Council Regulation (EU) 2018/120 of 23 January 2018 fixing for 2018 the fishing opportunities for certain fish stocks and groups of fish stocks, applicable in Union waters and, for Union fishing vessels, in certain non-Union waters, and amending Regulatio, Off. J. Eur. Union. 27 (2018) 1-168. https://eur-lex.europa.eu/legal647

[44] H.D. Gerritsen, C. Lordan, C. Minto, S.B.M. Kraak, Spatial patterns in the retained catch composition of Irish demersal otter trawlers: High-resolution fisheries data as a management tool, Fish. Res. 129-130 (2012) 127-136. doi:10.1016/j.fishres.2012.06.019.

[45] J.R. Ellis, S.P. Milligan, L. Readdy, N. Taylor, M.J. Brown, Spawning and nursery grounds of selected fish species in UK waters, in: Sci. Ser. Tech. Rep. 147, Lowestoft, 2012: p. 56.

content/EN/TXT/PDF/?uri=CELEX:32018R0120\&from=en.

Marine Institute, Atlas of the Commercial Fisheries Around Ireland, Oranmore, 2009.

http://oar.marine.ie/bitstream/10793/30/1/Atlas of the Commercial Fisheries Around Ireland 09.pdf.

[47] J. Feekings, V. Bartolino, N. Madsen, T. Catchpole, Fishery Discards : Factors Affecting Their Variability within a Demersal Trawl Fishery, PLoS One. 7 (2012) e36409. doi:10.1371/journal.pone.0036409.

[48] J.W. Valdemarsen, P. Suuronen, Modifying Fishing Gear to Achieve Ecosystem Objectives, in: M. Sinclair, G. Valdimarsson (Eds.), Responsible Fish. Mar. Ecosyst., CABI Publishing, Cambridge, 2003: pp. 321-342.

[49] SFPA, Fisheries Information Notice 4 of 2016 Protection of Stocks in the Celtic Sea, 2016. http://www.sfpa.ie/Portals/O/legislation/fins/2016/FIN 4-2016 Celtic Sea.pdf.

[50] L. Fauconnet, V.M. Trenkel, G. Morandeau, N. Caill-Milly, M.J. Rochet, Characterizing catches taken by different gears as a step towards evaluating fishing pressure on fish communities, Fish. Res. 164 (2015) 238-248. doi:10.1016/j.fishres.2014.11.019.

[51] V. Lauria, A.M. Power, C. Lordan, A. Weetman, M.P. Johnson, Spatial transferability of habitat suitability models of Nephrops norvegicus among fished areas in the northeast atlantic:

Sufficiently stable for marine resource conservation?, PLoS One. 10 (2015). doi:10.1371/journal.pone.0117006.

[52] M.P. Johnson, C. Lordan, A.M. Power, Habitat and Ecology of Nephrops norvegicus, Adv. Mar. Biol. 64 (2013) 27-63. doi:10.1016/B978-0-12-410466-2.00002-9.

[53] T.L. Catchpole, C.L.J. Frid, T.S. Gray, Resolving the discard problem-A case study of the English Nephrops fishery, Mar. Policy. 30 (2006) 821-831. doi:10.1016/j.marpol.2006.04.002.

[54] J.A. Mistiaen, I.E. Strand, Location Choice of Commercial Fishermen with Heterogeneous Risk Preferences, Am. J. Agric. Econ. 82 (2000) 1184-1190.

[55] A.S. Christensen, J. Raakjær, Fishermen's tactical and strategic decisions. A case study of Danish demersal fisheries, Fish. Res. 81 (2006) 258-267. doi:10.1016/j.fishres.2006.06.018.

[56] E. Macpherson, C.M. Duarte, Bathymetric trends in demersal fish size: Is there a general relationship?, Mar. Ecol. Ser. 71 (1991) 103-112. doi:10.3354/meps071103. 
[57] G. Petrakis, Day-night and depth effects on catch rates during trawl surveys in the North Sea, ICES J. Mar. Sci. 58 (2001) 50-60. doi:10.1006/jmsc.2000.0989.

[58] M. Labropoulou, D. Damalas, C. Papaconstantinou, Bathymetric trends in distribution and size of demersal fish species in the north Aegean Sea, in: J. Nat. Hist., 2008: pp. 673-686. doi:10.1080/00222930701835621.

[59] F.C. Neat, V. Bendall, B. Berx, P.J. Wright, M. Cuaig, B. Townhill, P.J. Schön, J. Lee, D. Righton, Movement of Atlantic cod around the British Isles: Implications for finer scale stock management, J. Appl. Ecol. 51 (2014) 1564-1574. doi:10.1111/1365-2664.12343.

[60] X. Zheng, G.J. Pierce, D.G. Reid, Spatial patterns of whiting abundance in Scottish waters and relationships with environmental variables, Fish. Res. 50 (2001) 259-270. doi:10.1016/S01657836(00)00219-8.

[61] S.J. Holmes, P.J. Wright, R.J. Fryer, Evidence from survey data for regional variability in cod dynamics in the North Sea and West of Scotland, ICES J. Mar. Sci. 65 (2008) 206-215. doi:10.1093/icesjms/fsm192.

[62] Anon, Atlas of Demersal Discarding. Scientific Observations and Potential Solutions, Marine Institute, Board lascaigh Mhara, 2011. ISBN 978-1-902895-50-5.

[63] S.J. Holmes, N. Bailey, N. Campbell, R. Catarino, K. Barratt, A. Gibb, P.G. Fernandes, Using fishery-dependent data to inform the development and operation of a co-management initiative to reduce cod mortality and cut discards, ICES J. Mar. Sci. 68 (2011) 1679-1688. doi:10.1093/icesjms/fsr101.

[64] A.S. Little, C.L. Needle, R. Hilborn, D.S. Holland, T. Marshall, Real-time spatial management approaches to reduce bycatch and discards: experiences from Europe and the United States, Fish Fish. 16 (2015) 576-602. doi:10.1111/faf.12080.

[65] S. Eliasen, N. Bichel, Fishers sharing real-time information about "bad" fishing locations. A tool for quota optimisation under a regime of landing obligations, Mar. Policy. 64 (2015) 1623. doi:10.1016/j.marpol.2015.11.007.

[66] H.M. Condie, A. Grant, T.L. Catchpole, Incentivising selective fishing under a policy to ban discards; lessons from European and global fisheries, Mar. Policy. 45 (2014) 287-292. doi:10.1016/j.marpol.2013.09.001. 
A.

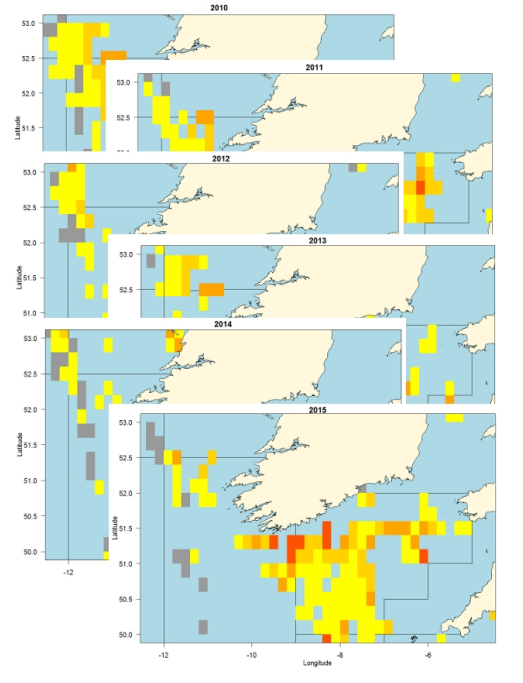

B.

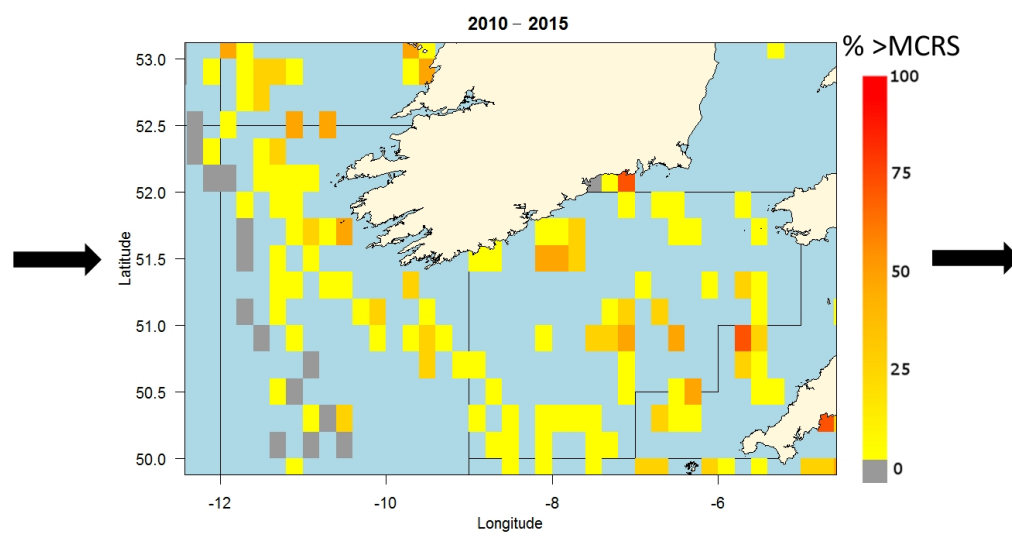

C.

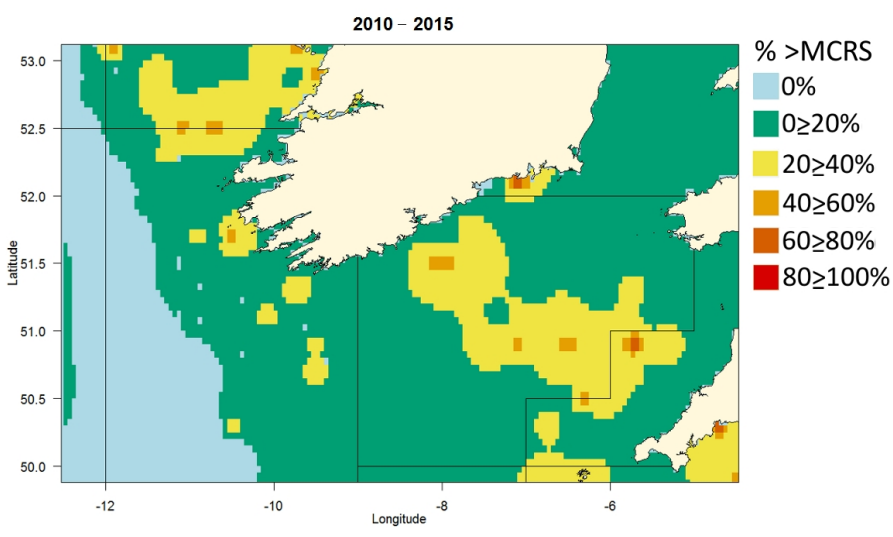




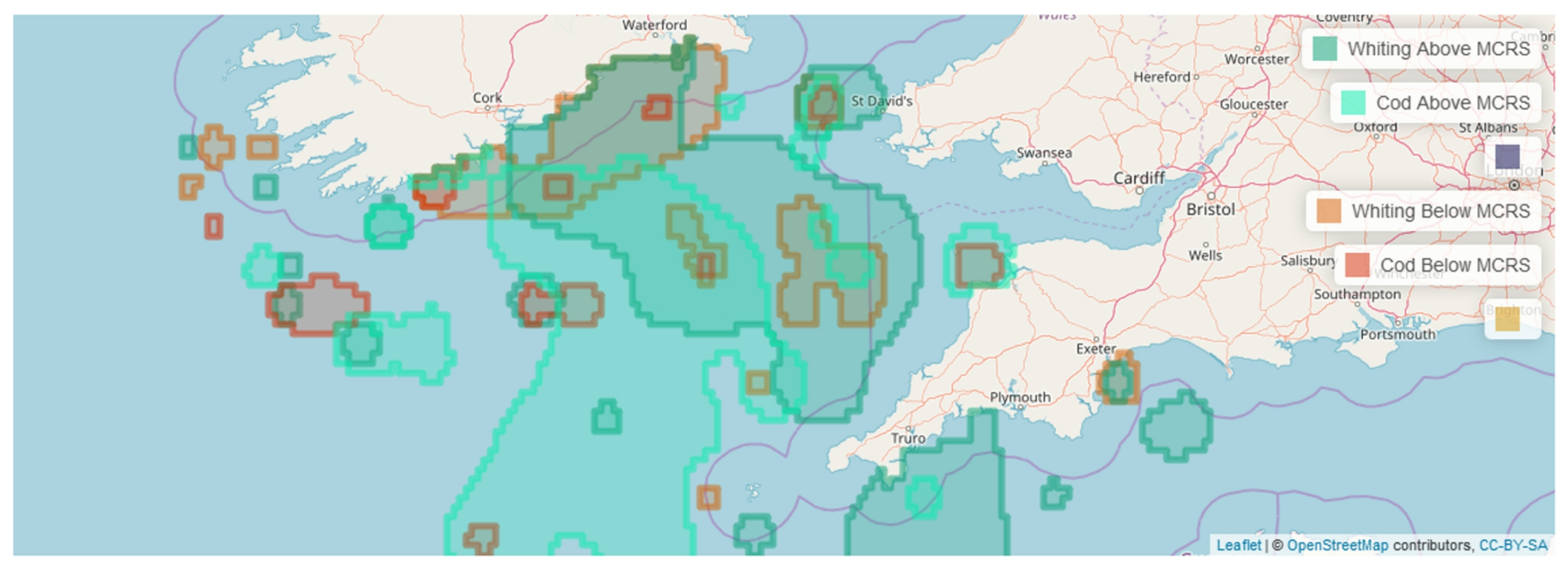

\section{CPUE Map Comparison}

Season

Vessel type

TR1

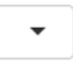

Target Species

Target Species \#1

Whiting

Target Species Size \#1

Above MCRS $\checkmark$

Max CPUE to target \#1$$
0
$$

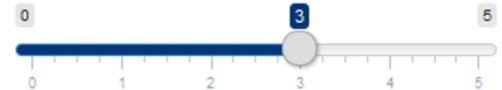

Target Species \#2

\begin{tabular}{llll|}
\hline Cod \\
Marget Species Size \#2 \\
Maxove MCRS CPUE to target \#2
\end{tabular}

Non-Target Species

Non-Target Species \#1

Whiting

Non-Target Species Size \#1

Below MCRS

Max CPUE to avoid \#1

$\circ$

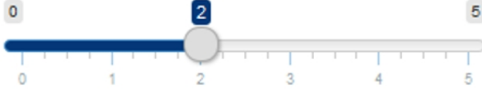

Non-Target Species \#2

Cod

Non-Target Species Size \#2

Below MCRS

Max CPUE to avoid \#2

0

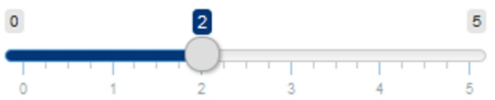


A.

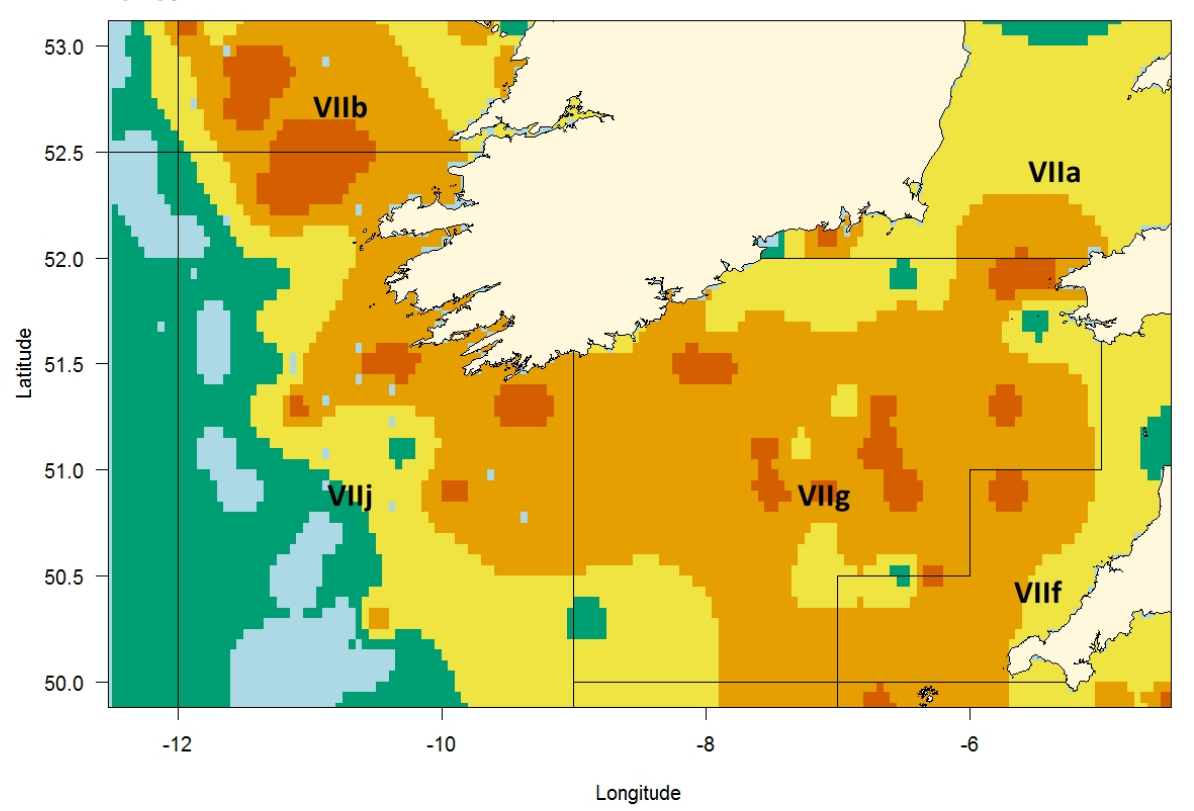

B.

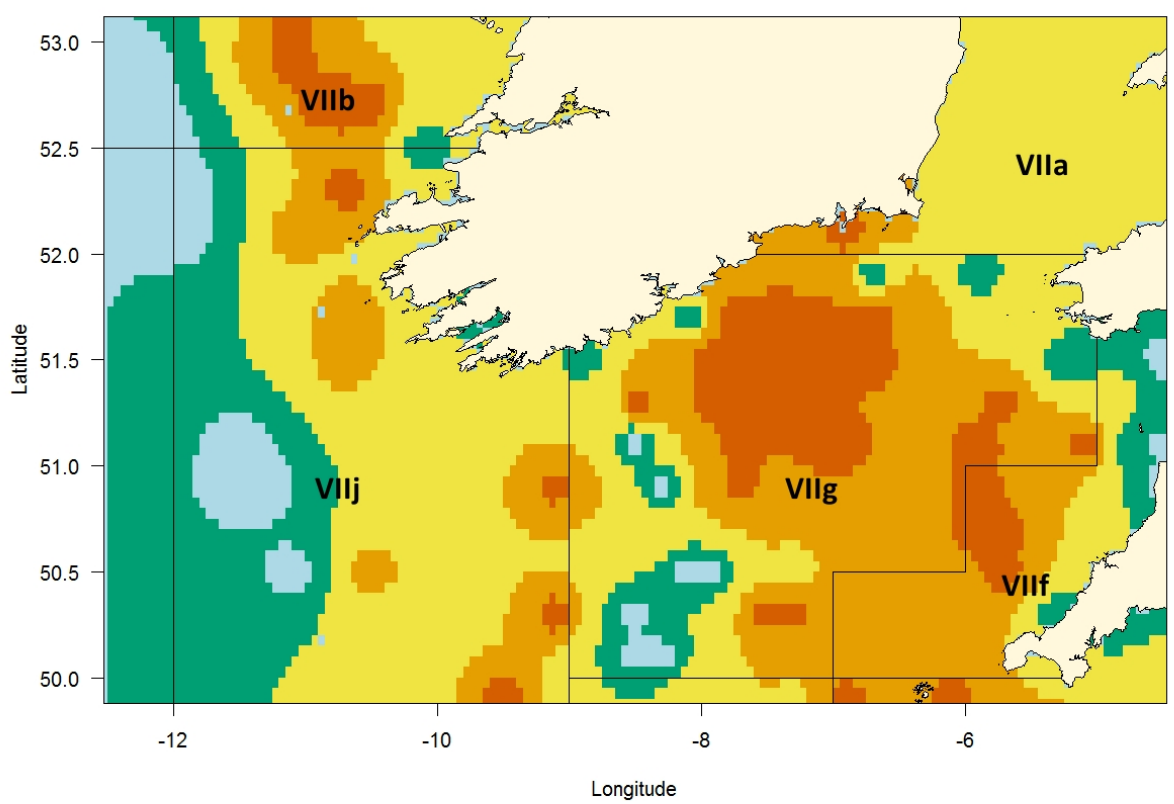

Legend

MIN — MAX 
A.

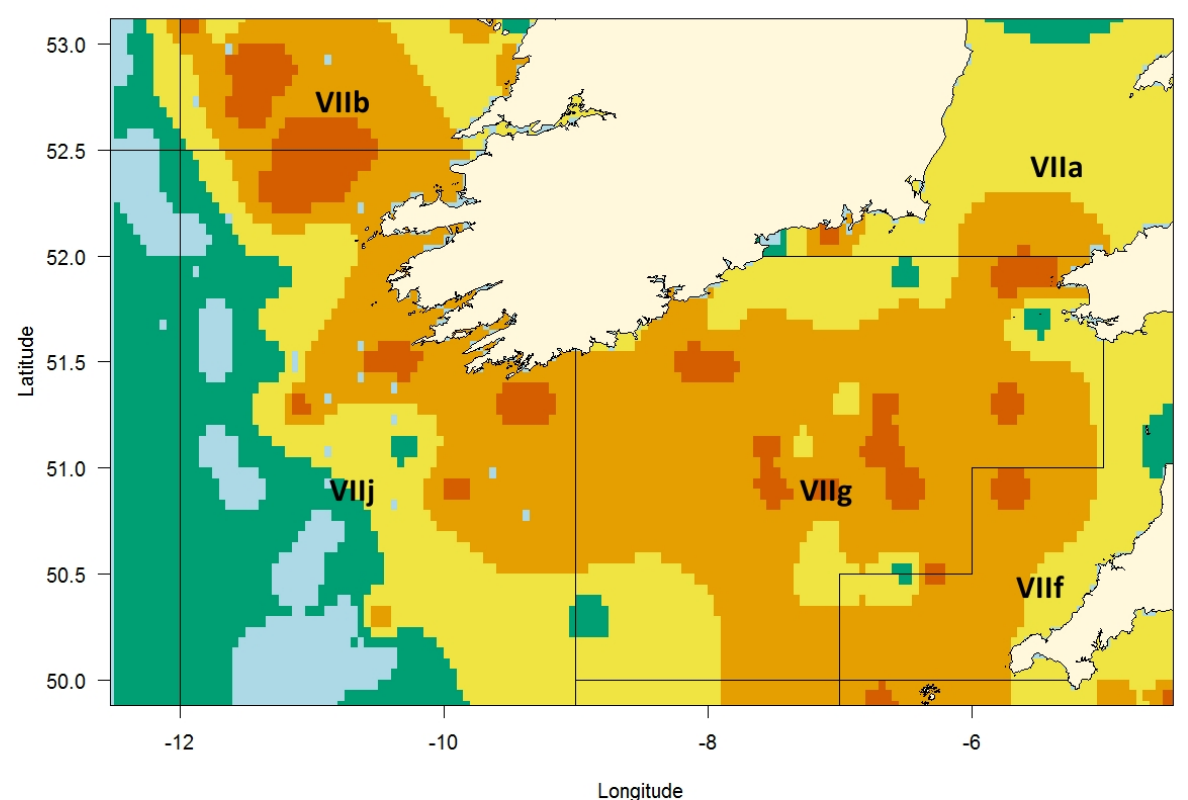

Legend
B.

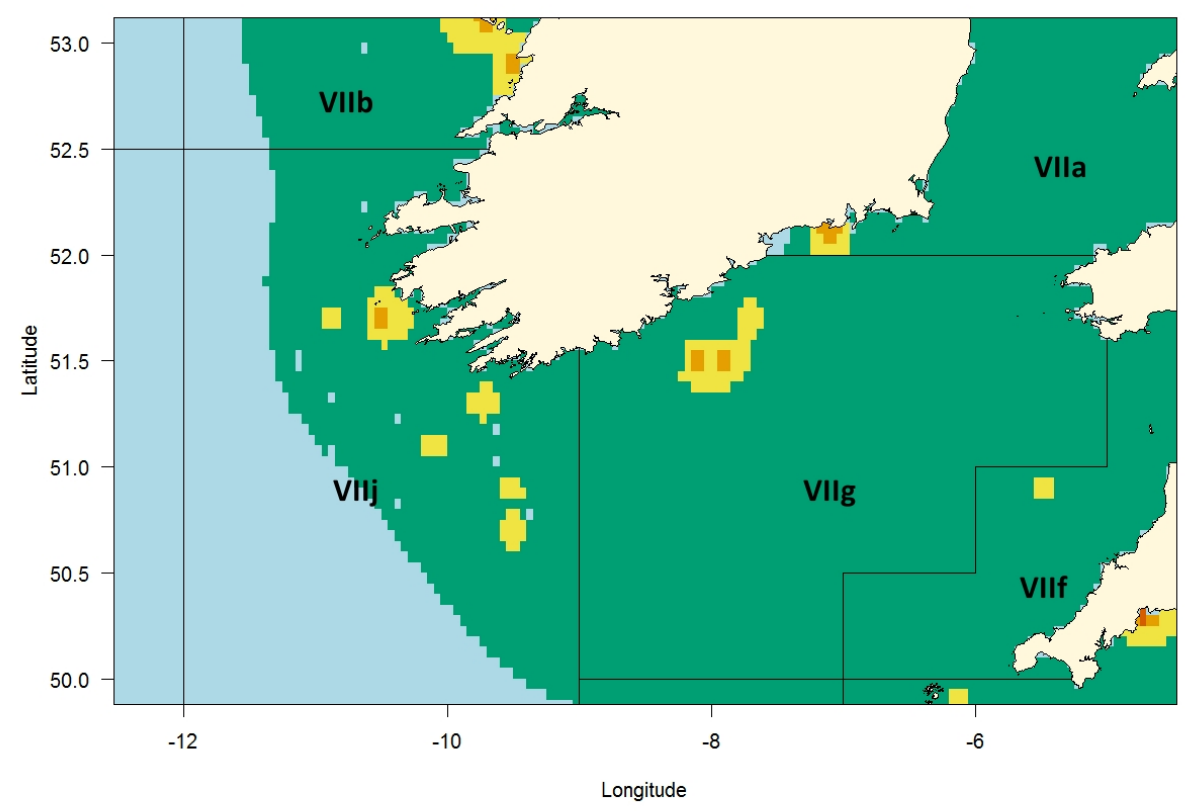

Legend

$0>20 \% \square 20>40 \% \square 40>60 \% \square 60>80 \% \square 80>100 \%$ 
A.

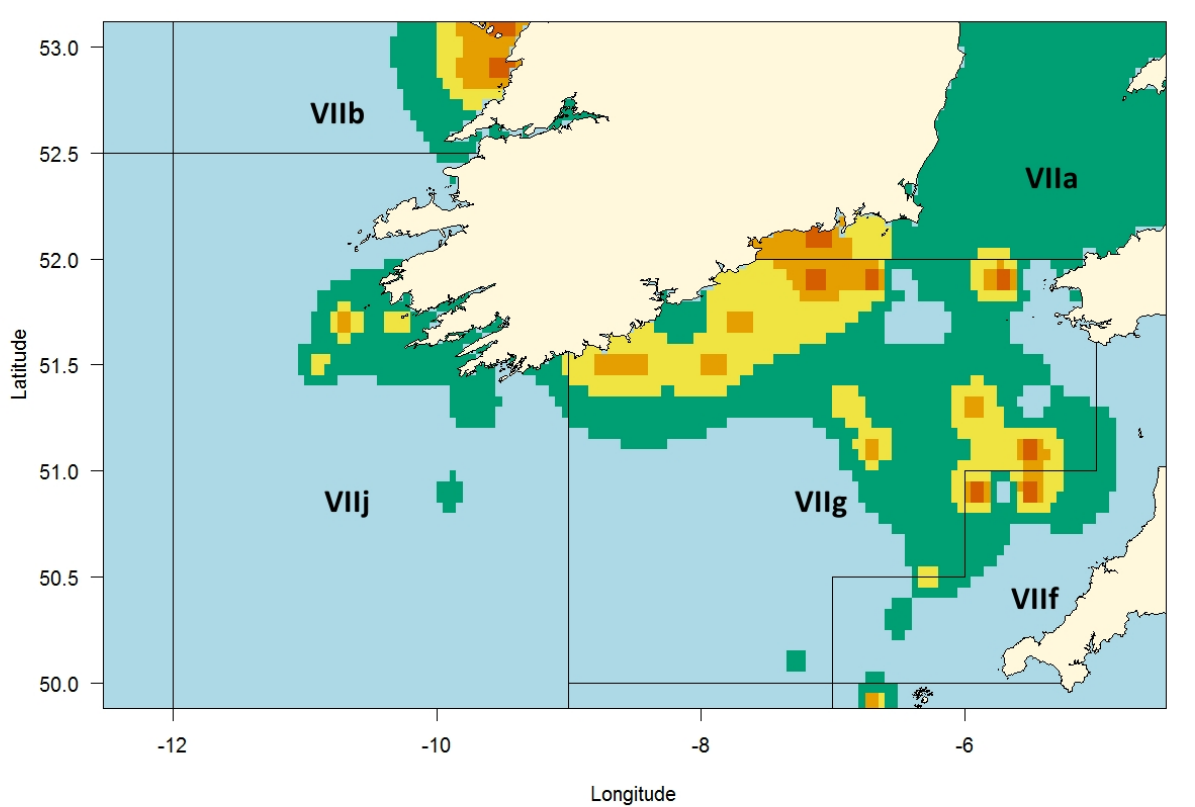

B.

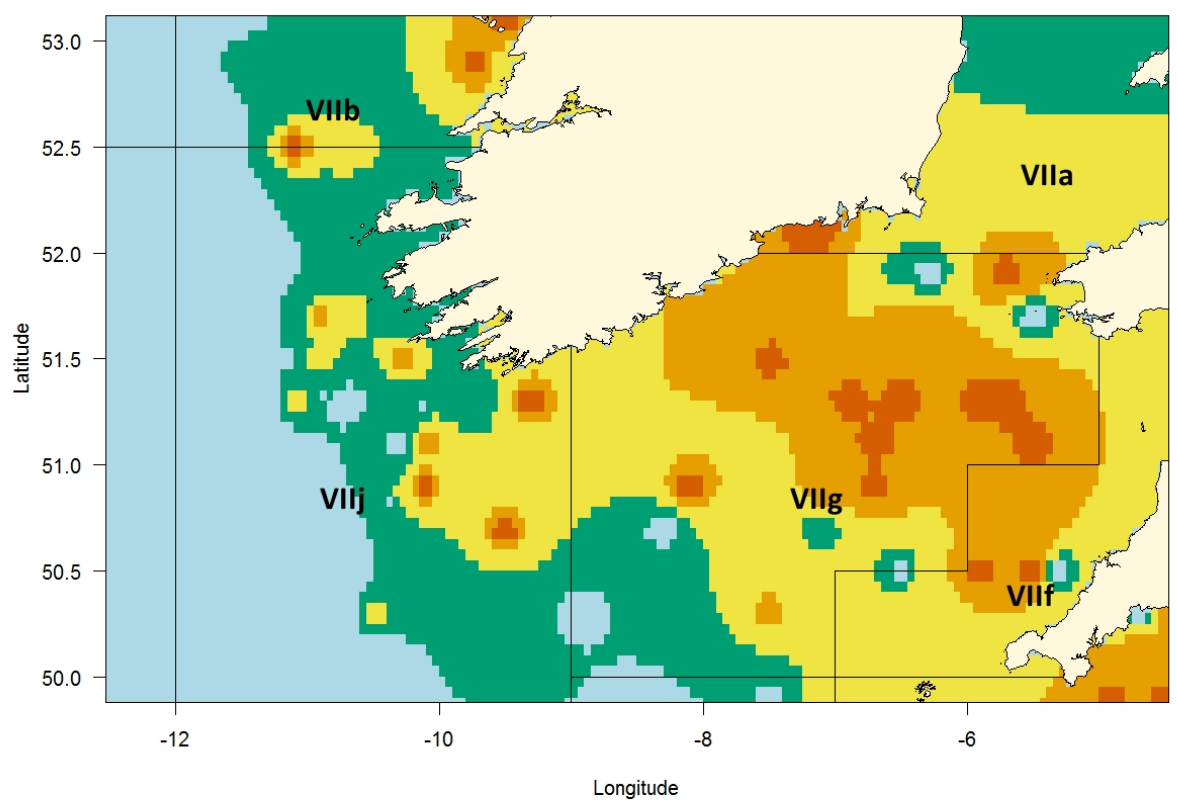

Legend

MIN $\square$ MAX 

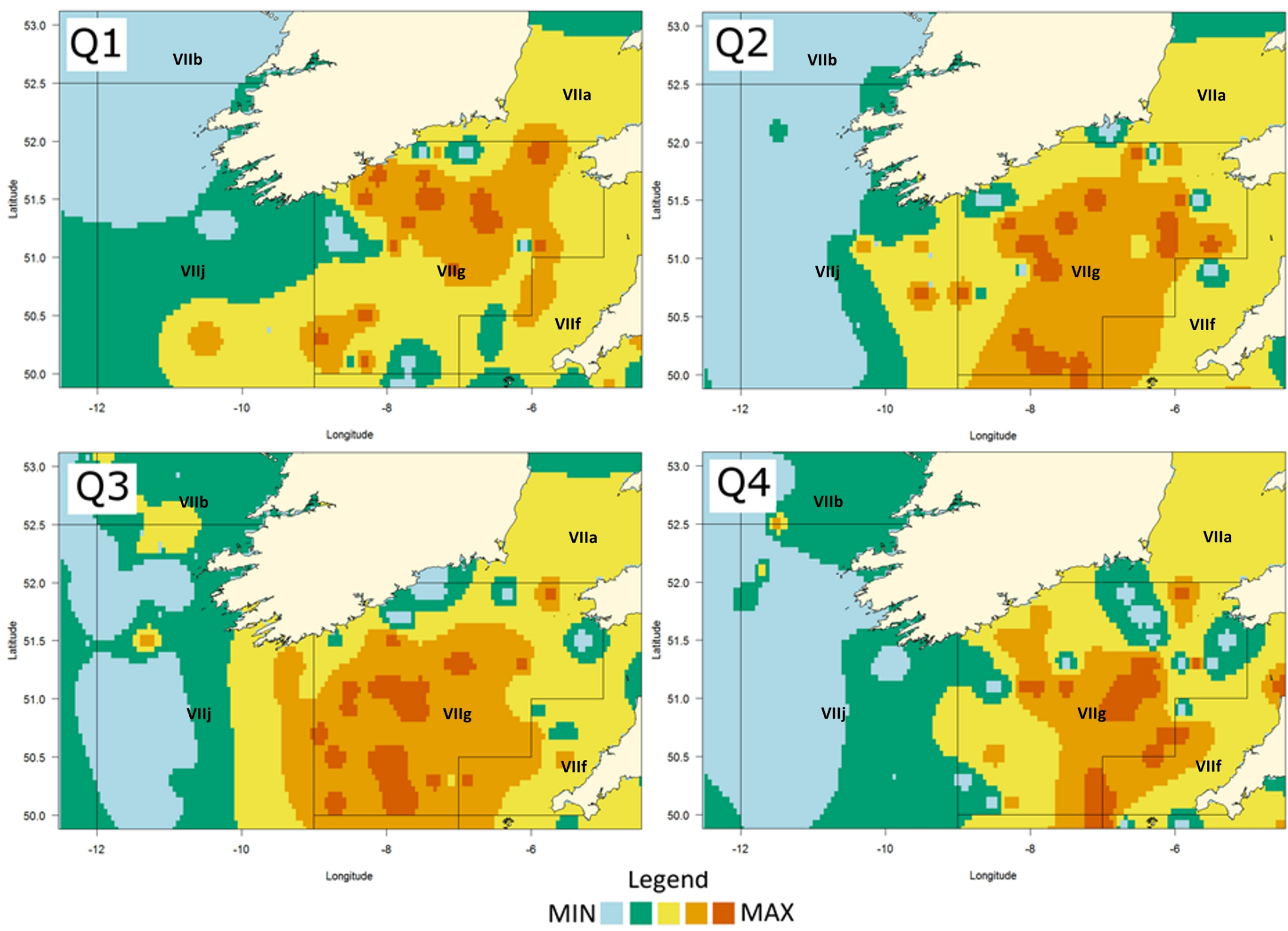
A.

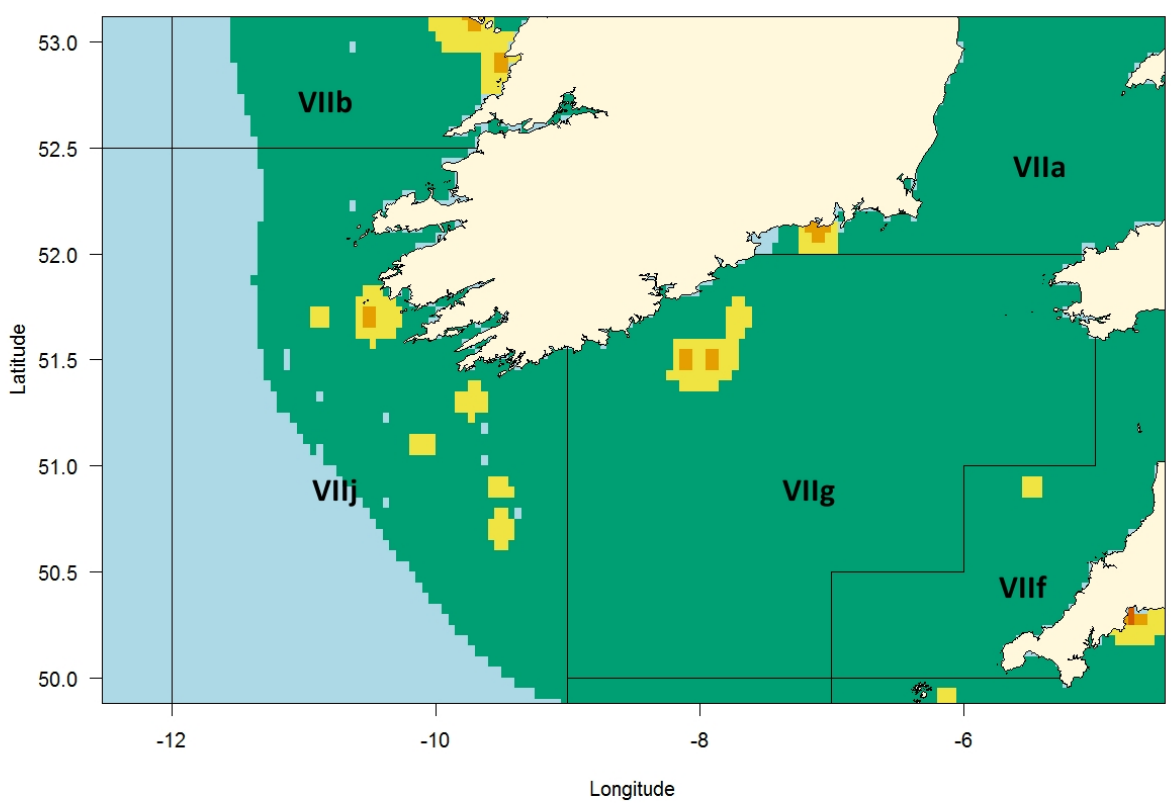

B.

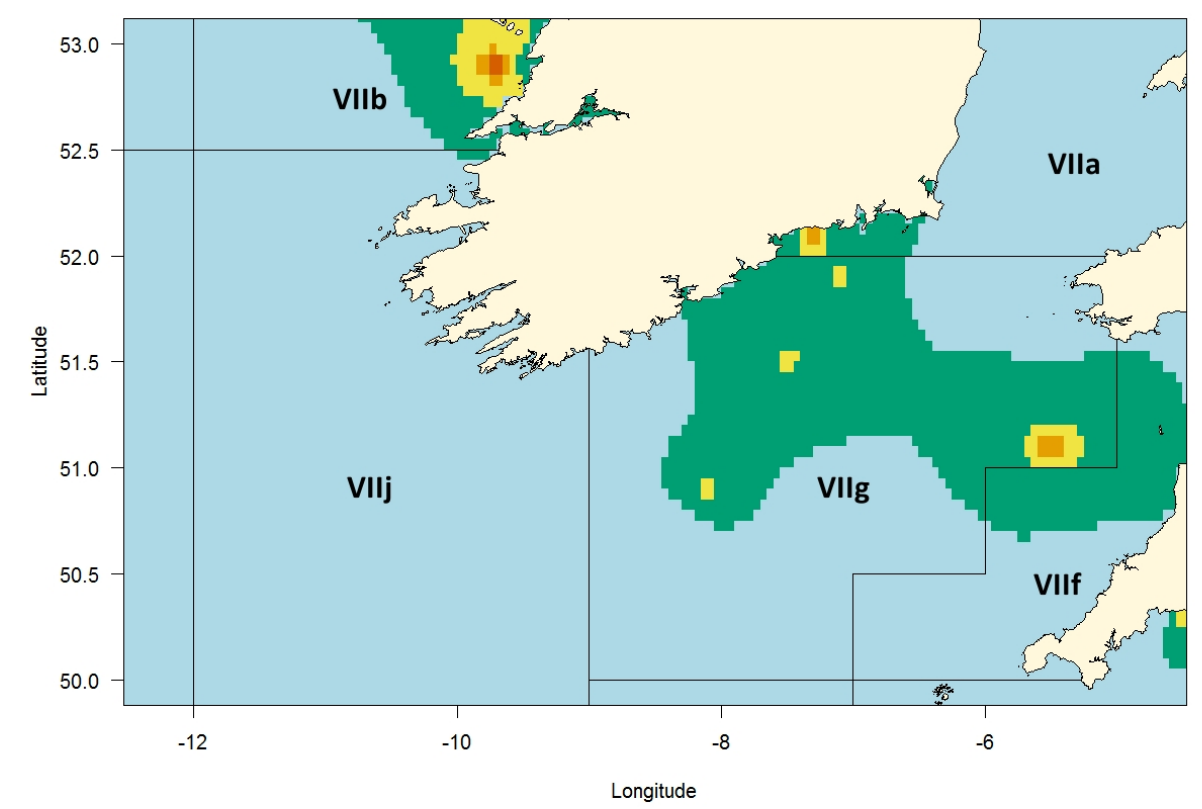

Legend

$0>20 \% \square 20>40 \% \square 40>60 \% \square 60>80 \% \square 80>100 \%$ 

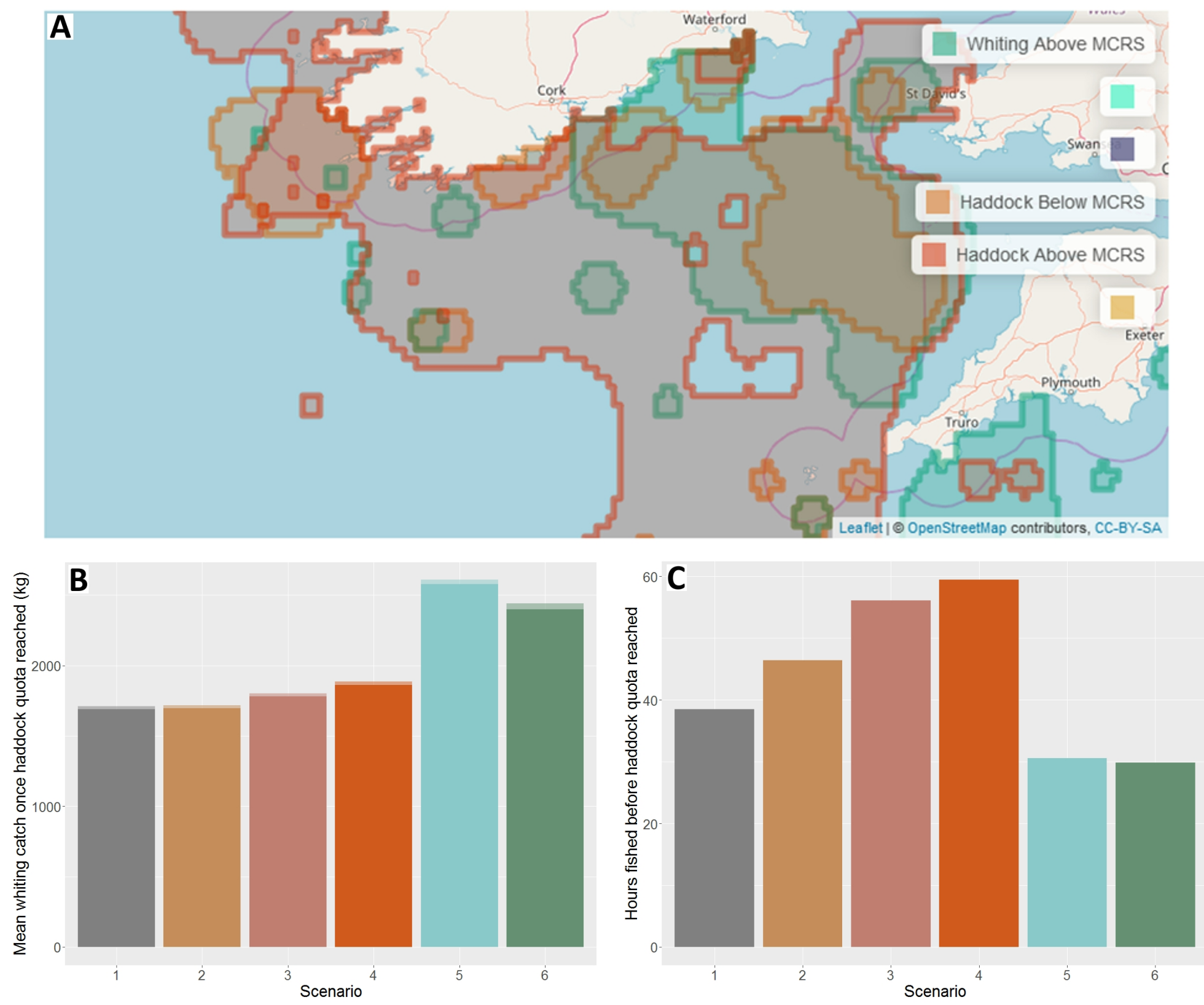

A.
B.

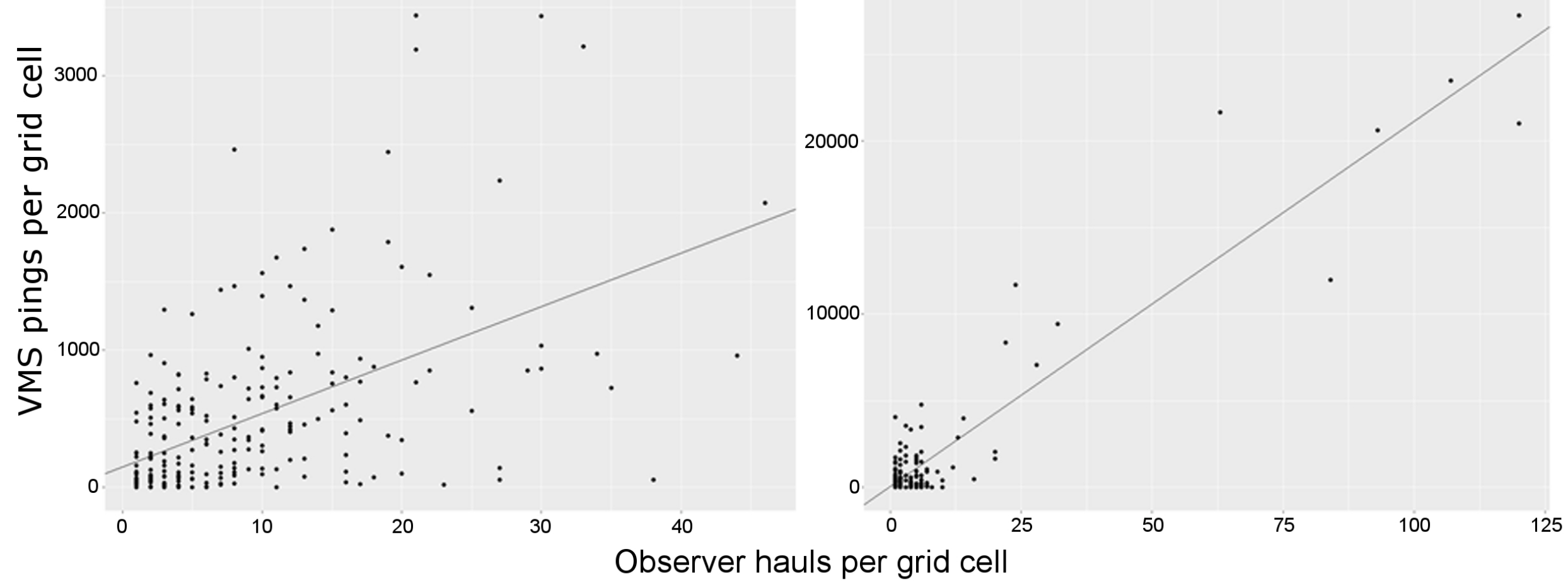


A B.
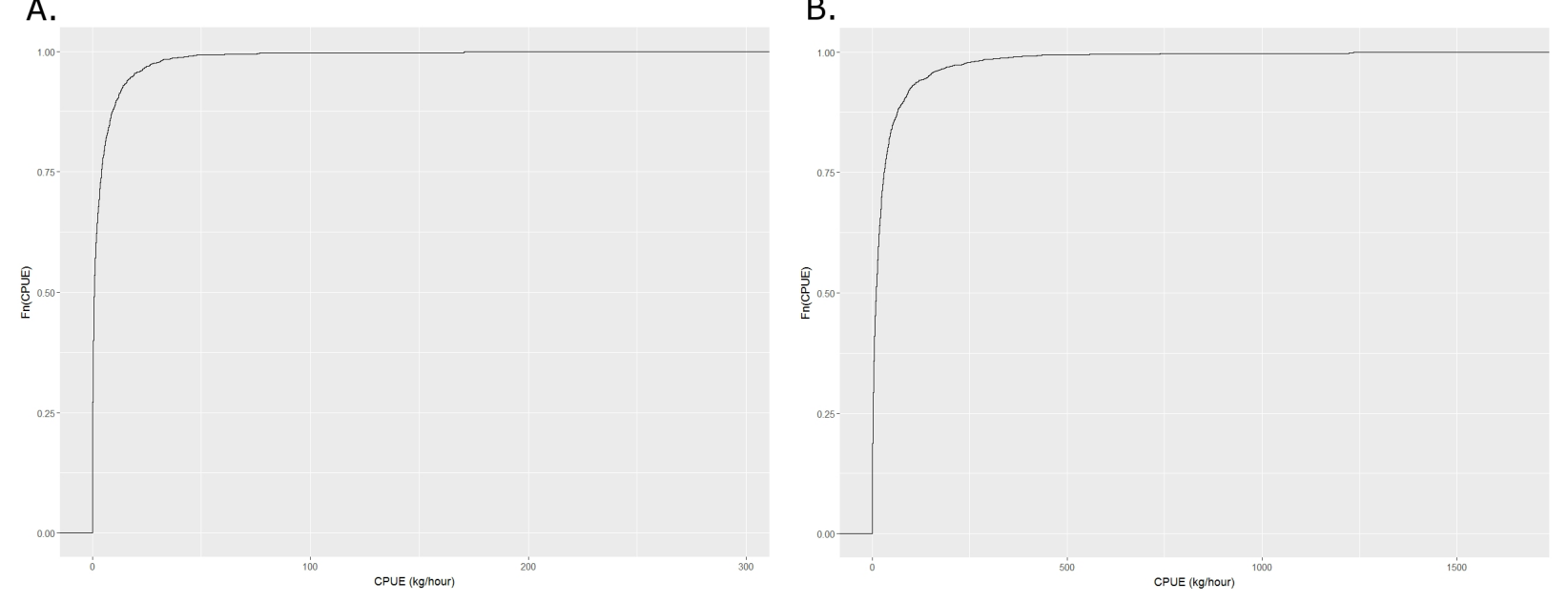

C. D.
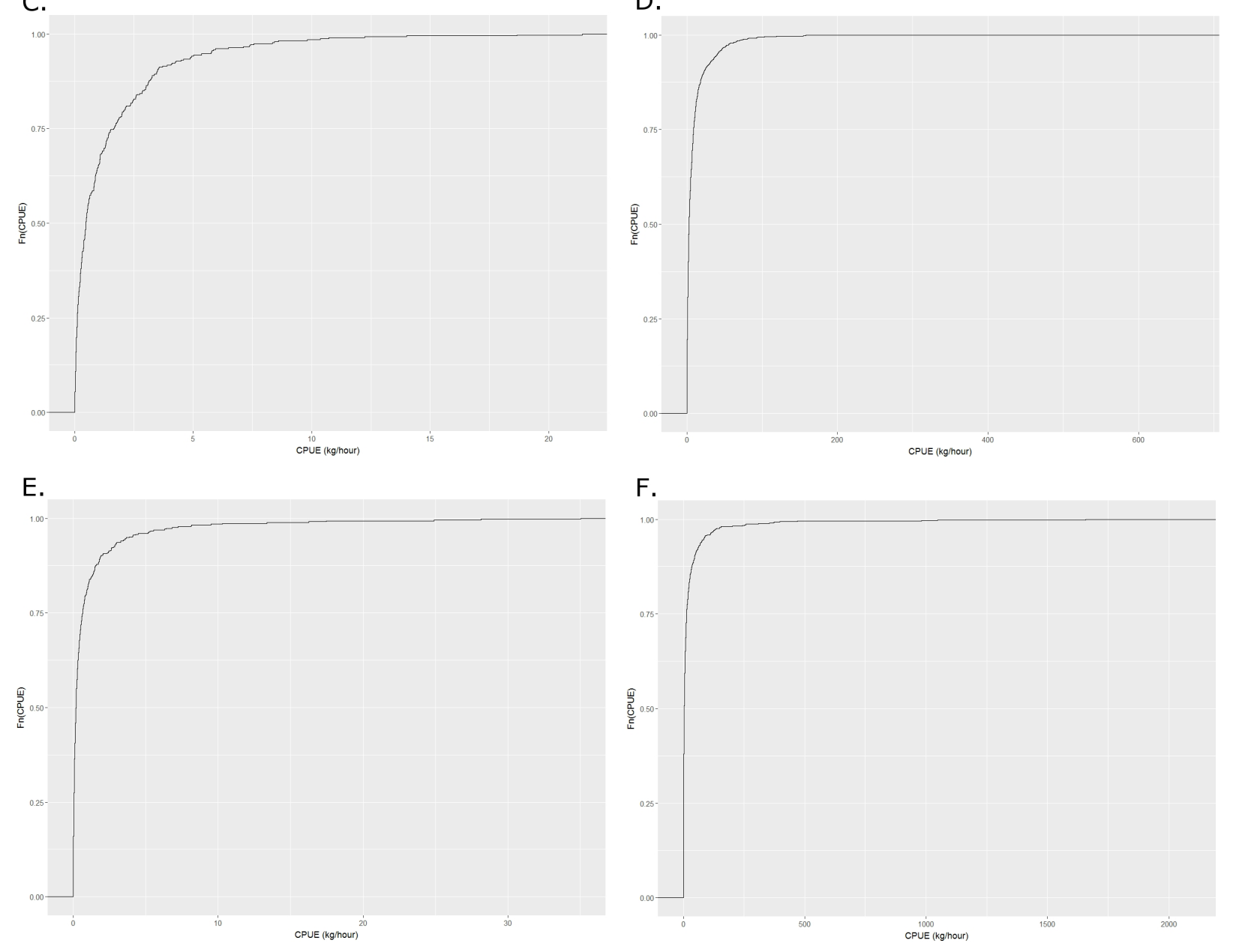
A.

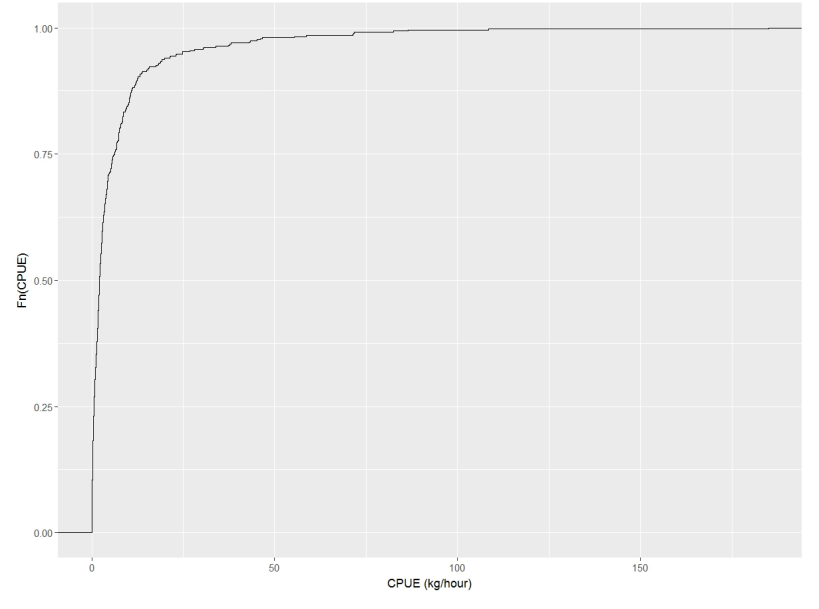

c.

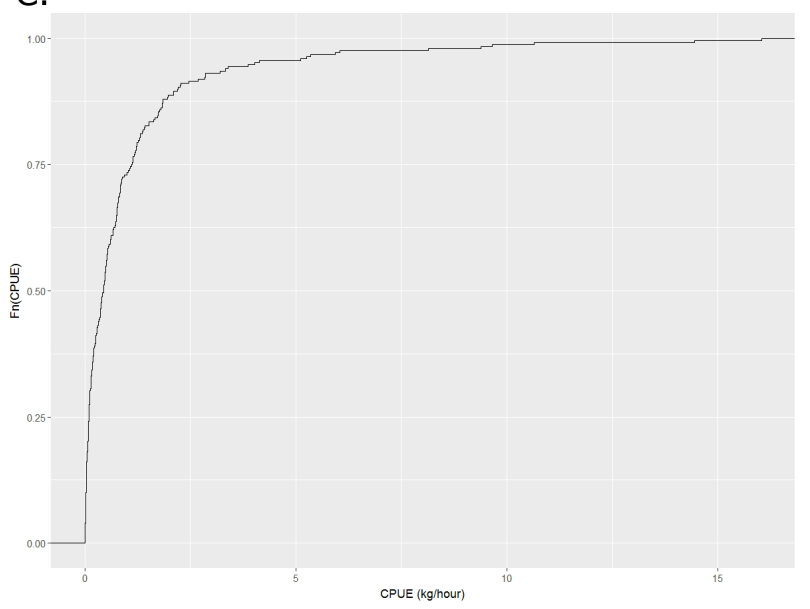

E.

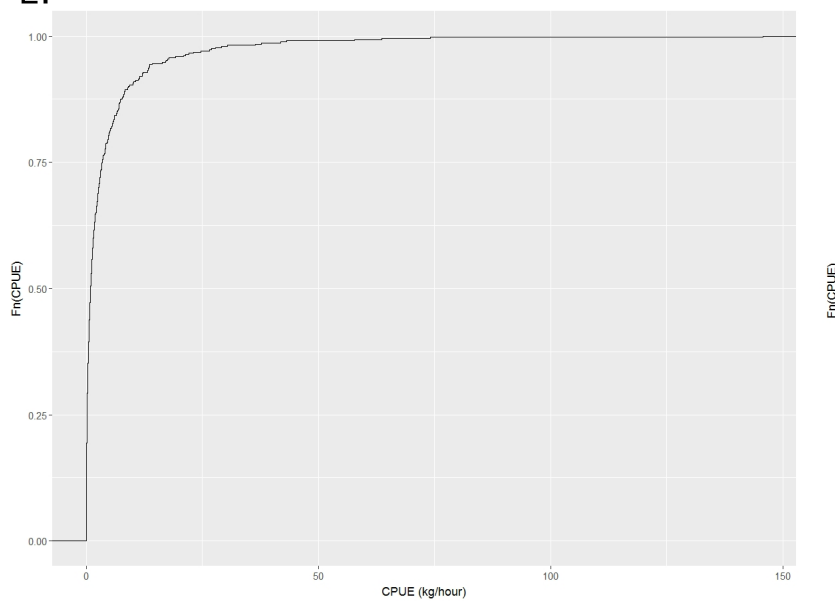

B.

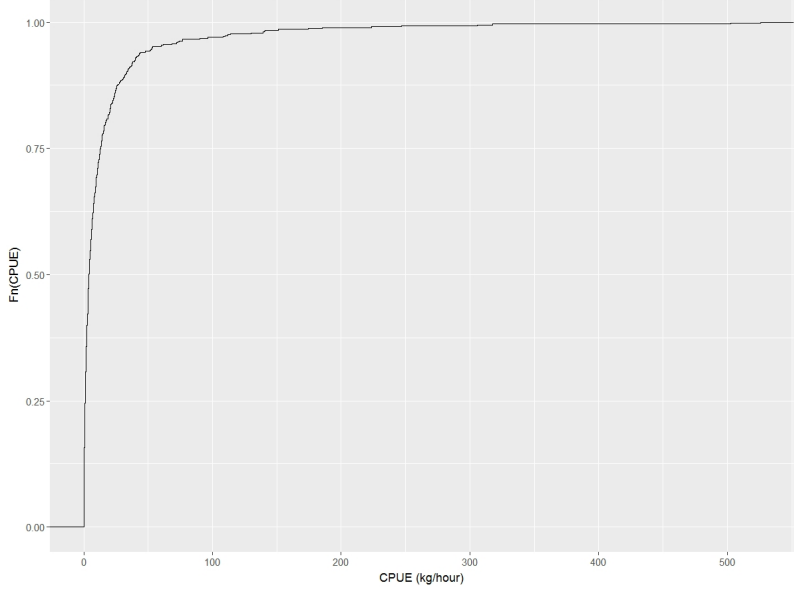

D.

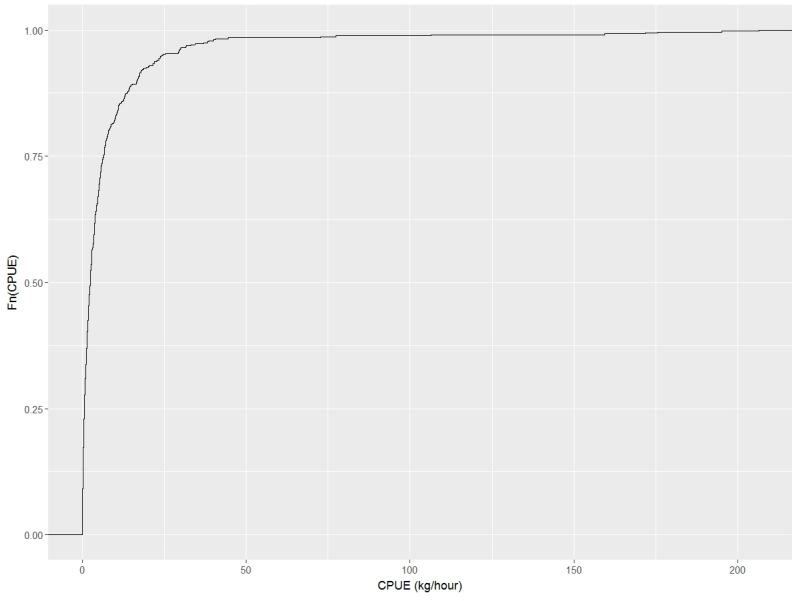

F.

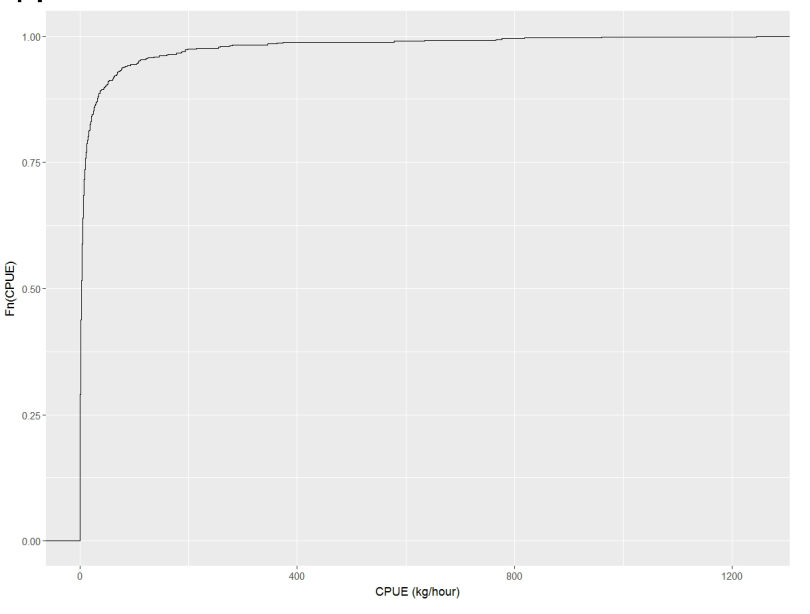


Figure 1. Diagram showing the steps in the map production process. (A. Individual binned maps created for each year; B. Amalgamated map for all years identifying grid cells within consistent binned categories over multiple years; C. Final interpolated map)

Figure 2. A screenshot of the shiny app developed to allow stakeholders to select the size, species and quantity of fish they would like to target and/or avoid during different seasons. The resultant map displays layers representing where to target or avoid fishing operations to optimise catch composition

Figure 3. Interpolated maps identifying area with consistent levels of >MCRS haddock CPUE over multiple years (2010-2015) for A. TR1 vessels and B. TR2 vessels

Figure 4. Interpolated maps identifying A. Areas with consistent levels of >MCRS haddock CPUE over multiple years (2010-2015) and B. Areas with consistent proportion of >MCRS haddock in the catch by weight over multiple years (2010-2015) for TR1 vessels

Figure 5. Interpolated maps identifying areas with consistent levels of whiting CPUE over multiple years (2010-2015) for A. Below MCRS fish and B. Above MCRS fish for TR1 vessels

Figure 6. Interpolated maps identifying areas with consistent levels of CPUE for above MCRS cod over multiple years (2010-2015) for each quarter of the year for TR1 vessels

Figure 7. Interpolated maps identifying areas with consistent levels of the proportion of above MCRS A. Haddock and B. Whiting in the catch over multiple years (2010-2015)

Figure 8. A. Map from shiny app showing overlap of layers for target and non-target species, B. Mean whiting catch at the point 2 tonne haddock quota is reached, $C$. Hours fished prior to haddock quota being reached, from modelling fishing of the Irish fleet under 6 different spatially restricted fishing scenarios (1. Unrestricted fishing, 2. Low <MCRS haddock CPUE (outside of orange map layer), 3. Low > MCRS haddock CPUE (outside of red map area), 4. Low haddock CPUE (outside of 2 and 3), 5. High whiting CPUE (inside green area), 6. High whiting and low haddock CPUE (where 5 does not overlap 4))

Supplementary Figure 1: Scatterplots examining the relationship between the number of observer hauls identified within $0.2^{\circ} \times 02^{\circ}$ gird cells in the Celtic Sea and the number of VMS pings associated with fishing activity (as defined by vessel speed) in the corresponding $0.2^{\circ} \times 02^{\circ}$ gird cell for $A$. TR1 vessels $\left(R^{2}=0.53, p<0.001 f=97.36, d f=1\right)$ and $B$. TR2 vessels $\left(R^{2}=0.94\right.$, $p<0.001 \mathrm{f}=1005, \mathrm{df}=1$ ) for data collected between 2010 and 2015 .

Supplementary Figure 2: Empirical distributions for the mean catch per unit effort data (kg per hour) from amalgamated grid cells for TR1 vessels for A. <MCRS haddock, B. $>$ MCRS haddock, C. $<$ MCRS cod, D. >MCRS cod, E. <MCRS whiting \& F. >MCRS whiting

Supplementary Figure 3: Empirical distributions for the mean catch per unit effort data (kg per hour) from amalgamated grid cells for TR2 vessels for A. <MCRS haddock, B. >MCRS haddock, C. $<$ MCRS cod, D. >MCRS cod, E. <MCRS whiting \& F. >MCRS whiting 


\begin{tabular}{|c|c|c|c|c|c|c|c|c|c|}
\hline \multicolumn{10}{|c|}{ TR1 Gears (bottom trawls, Danish seines and similar towed gears with mesh sizes $\geq 100 \mathrm{~mm}$} \\
\hline \multirow[b]{2}{*}{ Quarter } & \multirow[b]{2}{*}{ Gear Type } & \multicolumn{2}{|c|}{ Ireland } & \multicolumn{2}{|c|}{ France } & \multicolumn{2}{|c|}{ UK } & \multirow{2}{*}{$\begin{array}{l}\text { Total } \\
\text { hauls }\end{array}$} & \multirow{2}{*}{$\begin{array}{l}\text { Total } \\
\text { trips }\end{array}$} \\
\hline & & Hauls & Trips & Hauls & Trips & Hauls & Trips & & \\
\hline \multirow[t]{4}{*}{ Q1 } & ОтВ & 292 & 29 & 76 & 8 & 32 & 9 & 400 & 46 \\
\hline & OTT & 196 & 19 & 354 & 28 & 37 & 3 & 587 & 50 \\
\hline & SSC & 87 & 8 & - & - & - & - & 87 & 8 \\
\hline & SDN & - & - & 21 & 1 & - & - & 21 & 1 \\
\hline \multicolumn{2}{|l|}{ Total Q1 } & 575 & 56 & 451 & 37 & 69 & 12 & 1095 & 105 \\
\hline \multirow[t]{6}{*}{ Q2 } & OTB & 416 & 31 & 166 & 12 & 17 & 8 & 599 & 51 \\
\hline & OTQ & 22 & 2 & - & - & - & - & 22 & 2 \\
\hline & OTT & 398 & 33 & 395 & 30 & 19 & 1 & 812 & 64 \\
\hline & PTB & 5 & 1 & - & - & 2 & 1 & 7 & 2 \\
\hline & SSC & 142 & 11 & - & - & - & - & 142 & 11 \\
\hline & SDN & - & - & 63 & 4 & - & - & 63 & 4 \\
\hline \multicolumn{2}{|l|}{ Total Q2 } & 983 & 78 & 624 & 46 & 38 & 10 & 1645 & 134 \\
\hline \multirow[t]{4}{*}{ Q3 } & OTB & 388 & 35 & 315 & 23 & 18 & 7 & 721 & 65 \\
\hline & OTT & 298 & 24 & 478 & 41 & 42 & 4 & 818 & 69 \\
\hline & SSC & 32 & 4 & - & - & - & - & 32 & 4 \\
\hline & SDN & - & - & 99 & 6 & - & - & 99 & 3 \\
\hline \multicolumn{2}{|l|}{ Total Q3 } & 718 & 63 & 892 & 70 & 60 & 11 & 1670 & 144 \\
\hline \multirow[t]{4}{*}{ Q4 } & OTB & 259 & 24 & 276 & 28 & 35 & 11 & 570 & 63 \\
\hline & OTT & 112 & 11 & 296 & 24 & 30 & 3 & 438 & 38 \\
\hline & SDN & 15 & 1 & - & - & - & - & 15 & 1 \\
\hline & SSC & 12 & 3 & - & - & - & - & 12 & 3 \\
\hline \multicolumn{2}{|l|}{ Total Q4 } & 398 & 39 & 572 & 52 & 65 & 14 & 1035 & 105 \\
\hline
\end{tabular}

Table 1: Table detailing the number of hauls sampled, and trips in which they occurred in the TR1 data set used to construct hotspot maps. Numbers detailed based on country, quarter and gear type (OTB=Bottom Otter Trawl, OTQ= Otter Quad Trawl, OTT= Otter Twin Trawl, PTB= Bottom Pair Trawl, SSC $=$ Scottish Seine, SDN= Danish Seine) 


\begin{tabular}{|c|c|c|c|c|c|c|c|c|c|}
\hline \multicolumn{8}{|c|}{$\begin{array}{l}\text { TR2 Gears (bottom trawls, Danish seines and similar towed gears with mesh } \\
\text { sizes } 70 \mathrm{~mm}<100 \mathrm{~mm}\end{array}$} & \multirow{3}{*}{$\begin{array}{l}\text { Total } \\
\text { hauls }\end{array}$} & \multirow{3}{*}{$\begin{array}{l}\text { Total } \\
\text { trips }\end{array}$} \\
\hline \multirow[b]{2}{*}{ Quarter } & \multirow[b]{2}{*}{ Gear Type } & \multicolumn{2}{|c|}{ Ireland } & \multicolumn{2}{|c|}{ France } & \multicolumn{2}{|c|}{ UK } & & \\
\hline & & Hauls & Trips & Hauls & Trips & Hauls & Trips & & \\
\hline \multirow[t]{4}{*}{ Q1 } & OTB & 137 & 15 & 114 & 33 & 73 & 34 & 324 & 82 \\
\hline & отQ & 223 & 15 & - & - & - & - & 223 & 15 \\
\hline & OTT & 204 & 27 & 57 & 7 & 48 & 15 & 309 & 49 \\
\hline & SDN & - & - & 28 & 2 & - & - & 28 & 2 \\
\hline \multicolumn{2}{|l|}{ Total Q1 } & 564 & 57 & 199 & 42 & 121 & 49 & 884 & 148 \\
\hline \multirow[t]{4}{*}{ Q2 } & OTB & 169 & 22 & 190 & 57 & 96 & 40 & 455 & 119 \\
\hline & OTQ & 109 & 9 & - & - & - & - & 109 & 9 \\
\hline & OTT & 372 & 38 & 132 & 17 & 91 & 22 & 595 & 77 \\
\hline & SDN & - & - & 13 & 3 & - & - & 13 & 3 \\
\hline \multicolumn{2}{|l|}{ Total Q2 } & 650 & 69 & 335 & 77 & 187 & 62 & 1172 & 208 \\
\hline \multirow[t]{4}{*}{ Q3 } & OTB & 153 & 18 & 305 & 69 & 107 & 42 & 565 & 129 \\
\hline & оTQ & 83 & 9 & - & - & - & - & 83 & 9 \\
\hline & OTT & 179 & 19 & 51 & 7 & 27 & 5 & 257 & 31 \\
\hline & SDN & - & - & 43 & 3 & - & - & 43 & 3 \\
\hline \multicolumn{2}{|l|}{ Total Q3 } & 415 & 46 & 399 & 79 & 134 & 47 & 948 & 172 \\
\hline \multirow[t]{4}{*}{ Q4 } & OTB & 78 & 11 & 163 & 37 & 95 & 39 & 336 & 87 \\
\hline & отQ & 40 & 4 & - & - & - & - & 40 & 4 \\
\hline & OTT & 132 & 14 & 112 & 6 & 82 & 20 & 326 & 40 \\
\hline & SDN & - & - & 30 & 5 & - & - & 30 & 5 \\
\hline \multicolumn{2}{|l|}{ Total Q4 } & 250 & 29 & 305 & 48 & 177 & 59 & 732 & 136 \\
\hline
\end{tabular}

Table 2: Table detailing the number of hauls sampled, and trips in which they occurred in the TR2 data set used to construct hotspot maps. Numbers detailed based on country, quarter and gear type (OTB=Bottom Otter Trawl, OTQ= Otter Quad Trawl, OTT= Otter Twin Trawl, SDN= Danish Seine) 


\begin{tabular}{|l|c|c|c|c|c|c|c|c|}
\hline \multirow{2}{*}{} & \multicolumn{4}{|c|}{ Proportion data } & \multicolumn{4}{c|}{ CPUE data } \\
\hline & \multicolumn{2}{|c|}{ TR1 } & \multicolumn{2}{c|}{ TR2 } & \multicolumn{2}{c|}{ TR1 } & \multicolumn{3}{c|}{ TR2 } \\
\hline & Hotspot & Mean & Hotspot & Mean & Hotspot & Mean & Hotspot & Mean \\
\hline Haddock >MCRS & $0.22 \pm 0.06$ & $0.20 \pm 0.05$ & $0.43 \pm 0.01$ & $0.19 \pm 0.05$ & $0.27 \pm 0.06$ & $0.19 \pm 0.04$ & $0.53 \pm 0.10$ & $0.17 \pm 0.04$ \\
\hline Haddock <MCRS & $0.25 \pm 0.06$ & $0.13 \pm 0.04$ & $0.51 \pm 0.06$ & $0.31 \pm 0.05$ & $0.32 \pm 0.07$ & $0.001 \pm 0.09$ & $0.38 \pm 0.07$ & $0.07 \pm 0.09$ \\
\hline Cod >MCRS & $0.37 \pm 0.06$ & $0.14 \pm 0.04$ & $0.17 \pm 0.06$ & $0.09 \pm 0.04$ & $0.37 \pm 0.06$ & $0.18 \pm 0.03$ & $0.24 \pm 0.07$ & $0.13 \pm 0.03$ \\
\hline Cod <MCRS & $0.27 \pm 0.06$ & $0.21 \pm 0.04$ & $0.26 \pm 0.07$ & $0.15 \pm 0.04$ & $0.22 \pm 0.08$ & $-0.01 \pm 0.08$ & $0.19 \pm 0.08$ & $0.01 \pm 0.09$ \\
\hline Whiting > MCRS & $0.43 \pm 0.06$ & $0.39 \pm 0.05$ & $0.16 \pm 0.06$ & $0.21 \pm 0.05$ & $0.31 \pm 0.07$ & $-0.01 \pm 0.08$ & $0.27 \pm 0.07$ & $0.14 \pm 0.04$ \\
\hline Whiting < MCRS & $0.25 \pm 0.06$ & $0.16 \pm 0.04$ & $0.27 \pm 0.06$ & $0.16 \pm 0.05$ & $0.41 \pm 0.06$ & $0.26 \pm 0.04$ & $0.16 \pm 0.07$ & $0.05 \pm 0.09$ \\
\hline
\end{tabular}

Table 3: Table to show mean Cohen's kappa values ( \pm SD) for agreement between test subset of observer data and results from two mapping methodologies for TR1 and TR2 vessels (mean per $0.2 \mathrm{x}$ 0.2 degree grid cell and for our hotspot mapping methodology) for proportion by weight maps and CPUE maps. Results are displayed for below and above MCRS haddock, cod and whiting. 